\title{
Virucidal Action Against Avian Influenza H5NI Virus and Immunomodulatory Effects of Nanoformulations Consisting of Mesoporous Silica Nanoparticles Loaded with Natural Prodrugs
}

This article was published in the following Dove Press journal:

International Journal of Nanomedicine

\author{
Khaled AbouAitah (1D) ${ }^{1,2}$ \\ Anna Swiderska-Sroda' \\ Ahmed Kandeil ${ }^{3}$ \\ Asmaa MM Salman ${ }^{4, \dagger}$ \\ Jacek Wojnarowicz $\mathbb{D}^{1}$ \\ Mohamed $\mathrm{A} \mathrm{Ali}^{3}$ \\ Agnieszka Opalinska' \\ Stanislaw Gierlotka' \\ Tomasz Ciach $\mathbb{D}^{5}$ \\ Witold Lojkowski (D) \\ 'Laboratory of Nanostructures and \\ Nanomedicine, Institute of High Pressure \\ Physics, Polish Academy of Sciences, \\ Warsaw, Poland; ${ }^{2}$ Medicinal and Aromatic \\ Plants Research Department, \\ Pharmaceutical and Drug Industries \\ Research Division, National Research \\ Centre (NRC), P.C.I2622, Dokki, Giza, \\ Egypt; ${ }^{3}$ Center of Scientific Excellence for \\ Influenza Viruses, Water Pollution \\ Research Department, Environmental \\ Research Division, National Research \\ Centre (NRC) P.C.I2622, Dokki, Giza, \\ Egypt; ${ }^{4}$ Medicinal and Pharmaceutical \\ Chemistry Department, Pharmaceutical \\ and Drug Industries Research Division, \\ National Research Centre (NRC), P.C. \\ 12622, Dokki, Giza, Egypt; ${ }^{5}$ Biomedical \\ Engineering Laboratory, Faculty of \\ Chemical and Process Engineering, \\ Warsaw University of Technology, \\ Warsaw, Poland
}

${ }^{\dagger}$ AMM Salman passed away on June 3, 2019

Correspondence: Khaled AbouAitah; Witold Lojkowski

Email k.abouaitah@labnano.pl;

w.lojkowski@labnano.pl
Background: Combating infectious diseases caused by influenza virus is a major challenge due to its resistance to available drugs and vaccines, side effects, and cost of treatment. Nanomedicines are being developed to allow targeted delivery of drugs to attack specific cells or viruses.

Materials and Methods: In this study, mesoporous silica nanoparticles (MSNs) functionalized with amino groups and loaded with natural prodrugs of shikimic acid ( $\mathrm{SH}$ ), quercetin (QR) or both were explored as a novel antiviral nanoformulations targeting the highly pathogenic avian influenza H5N1 virus. Also, the immunomodulatory effects were investigated in vitro tests and anti-inflammatory activity was determined in vivo using the acute carrageenan-induced paw edema rat model.

Results: Prodrugs alone or the MSNs displayed weaker antiviral effects as evidenced by virus titers and plaque formation compared to nanoformulations. The $\mathrm{MSNs}-\mathrm{NH}_{2}-\mathrm{SH}$ and MSNs- $\mathrm{NH}_{2}-\mathrm{SH}-\mathrm{QR} 2$ nanoformulations displayed a strong virucidal by inactivating the H5N1 virus. They induced also strong immunomodulatory effects: they inhibited cytokines (TNF- $\alpha$, IL-1 $\beta$ ) and nitric oxide production by approximately $50 \%$ for $\mathrm{MSNs}_{-} \mathrm{NH}_{2}-\mathrm{SH}-\mathrm{QR} 2$ (containing both $\mathrm{SH}$ and $\mathrm{QR}$ ). Remarkable anti-inflammatory effects were observed during in vivo tests in an acute carrageenan-induced rat model.

Conclusion: Our preliminary findings show the potential of nanotechnology for the application of natural prodrug substances to produce a novel safe, effective, and affordable antiviral drug.

Keywords: virucidal action, influenza H5N1 virus, immunomodulatory and antiinflammatory, nanoformulations-drug delivery system, shikimic acid and quercetin natural prodrugs, mesoporous silica nanoparticles

\section{Introduction}

Viral infections and the emergence of new strains resistant to therapeutic treatments are a significant global health challenge. ${ }^{1}$ Influenza A viruses (IAVs) are responsible for serious health threats worldwide and have considerable socioeconomic impacts. ${ }^{2-4}$ The highly pathogenic avian influenza virus (H5N1) can be transmitted to humans and an increased rate of infections is observed. ${ }^{5}$ Combating IAVs is one of the major challenges to date, as they have high genetic variability, and new strains of viruses appear ${ }^{6}$ that are resistant to available vaccines and drug inhibitors. ${ }^{7-10}$ Thus, new antiviral 
agents to prevent such medical threats that are safe and affordable are urgently needed. An ideal antiviral drug would have the following characteristics: broad spectrum, minimum toxicity, and a virucidal mechanism during the activity against various viruses. $^{11}$

Nanomedicine is a rapidly expanding interdisciplinary branch of medicine in which nanotechnology is used to create nanostructures to carry targeted and controlled release nanodrugs. ${ }^{12}$ The use of nanomaterials to inhibit viral diseases through direct interaction of the nanoparticles and viruses was reported previously. ${ }^{1,13,14}$ The antiviral effect is enhanced by the specific physicochemical properties of the used nanomaterials: small size, high surface area, surface modification. Examples are silver, ${ }^{15,16}$ copper iodide, ${ }^{17}$ graphene oxide, ${ }^{18}$ gold, ${ }^{19-21}$ and polymers, such as glycan. ${ }^{22}$ Because of their ability to encapsulate drugs with large payloads, the opportunity opens for developing promising antiviral nanoformulations as drug delivery systems, thus reducing negative side effects. ${ }^{23-25}$ Among the explored nanomaterials, modified silica nanoparticles have recently attracted much attention as antiviral agents. $^{26-28}$

In the present study, we tested the antiviral effect of mesoporous silica nanoparticles (MSNs), ie nanoporous silica spheres $100-200 \mathrm{~nm}$ in diameter with pores loaded with natural prodrugs. The particle size is comparable to virus size, and therefore their efficient attachment to viruses is expected. MSNs have been studied as a versatile drug delivery vehicle in in vitro and in vivo studies for various diseases. $^{29-33}$ They can be administered via injection (intravenous, hypodermic, or intramuscular) or orally and are eliminated through the urine and feces. ${ }^{34}$ MSNs have been used to enhance the solubility, targeting ability, and therapeutic activity with a combination of two or more drugs for dual therapeutic efficiency. Recently, the FDA classified silica as Generally Recognized as Safe (GRAS), allowing it to be used in cosmetics and food additives. ${ }^{35}$ The rationally tailored delivery system for antiviral drugs must consider the cytotoxicity of the used materials. MSNs are biocompatible and considered as non-toxic ${ }^{36}$ compared to other nanomaterials employed as antimicrobial agents. For example, silver nanoparticles exhibit considerable cytotoxic effects, even at low concentrations. ${ }^{37}$

In this study, we employed MSNs as a nanostructured targeted carrier of antiviral prodrug compounds shikimic acid (SH) or quercetin (QR) (as schematically shown in Figure $1 \mathrm{H})$. A novel nanoformulation against the highly pathogenic influenza virus H5N1 was developed. We chose these natural compounds due to their safety profiles, low cost, and small size. SH was selected because it is used as a precursor in the production of oseltamivir, commercially known as Tamiflu ${ }^{38,39}$ and other pharmaceutical agents. It is a precursor for several pharmaceutical compounds, including anti-pyretic, anti-oxidants, anti-coagulants, antithrombotic, anti-cancer, anti-inflammatory, etc. Thus, it is promising to investigate the possibility to apply nanoformulations loaded with $\mathrm{SH}$ as DDS against $\mathrm{H} 5 \mathrm{~N} 1$ virus. QR was selected due to its inhibition of influenza viruses. ${ }^{40,41}$ It has shown many pharmacological impacts in vitro and in vivo as one of the strongest anti-oxidant compounds.

Several studies have shown that secretion of proinflammatory immunomodulators, such as cytokines interleukin (IL)-1 $\beta$, tumor necrosis factor-alpha (TNF- $\alpha$ ), and nitric oxide (NO) free radicals, increases considerably during influenza infections. These pro-inflammatory mediators play a crucial role in the regulation of the innate and adaptive immune systems. ${ }^{42-46}$ Within this context, the proper antiinflammatory milieu is a key factor in counteracting viral infection. ${ }^{47}$ Thus, there is a need to modulate the inflammatory immune response and virucidal activity of $\mathrm{H} 5 \mathrm{~N} 1$ viruses. Therefore, we evaluated also the immunoregulatory and anti-inflammatory effect of the proposed prodrug-loaded MSNs. Combining antiviral and anti-inflammatory effects may have a positive impact on treating influenza viruses.

\section{Materials and Methods \\ Materials}

The list of all used materials is given in the supplementary information.

\section{Synthesis and Surface Modification of Mesoporous Silica Nanoparticles - MSNs}

The MSNs were prepared using the biphasic stratification method recently reported by Shen et $\mathrm{al}^{48}$ with minor modifications. The detailed steps of the procedure are given in the supplementary information. To functionalize the MSNs with amino groups, the reaction of aminopropyl groups of APTES molecules with their silanol groups by postsynthesis method were followed. The procedure was similar to that described elsewhere, ${ }^{49}$ and the resulting nanoparticles were denoted as MSNs- $\mathrm{NH}_{2}$.

\section{Preparation of Drug-Loaded Nanoformulations}

The prodrugs were loaded into the MSNs nanopores based on the solvent evaporation method, in which they were dissolved using a mixture solvent (ethanol/DMSO/acetone 
1:1:5). The loading ratio between the silica nanoparticles to prodrug was $1: 3$.

For loading QR into the modified nanoparticles, the following procedure was used: $300 \mathrm{mg}$ of $\mathrm{MSN}_{-} \mathrm{NH}_{2}$ powder was added to the solvent containing $100 \mathrm{mg}$ of QR (Sigma-Aldrich) and stirred for $24 \mathrm{~h}$ at room temperature. The solvent was subsequently evaporated at $50^{\circ} \mathrm{C}$ using the Rotavapor (Büchi, Switzerland), re-suspended in ultra-pure water to remove unloaded molecules, and dried at $40^{\circ} \mathrm{C}$ for $12 \mathrm{~h}$ in an oven. The evaporation and resuspension were repeated several times. The resulting product was denoted as $\mathrm{MSNs}-\mathrm{NH}_{2}-\mathrm{QR}$ nanoformulation.

For loading $\mathrm{SH}$ into $\mathrm{MSNs}-\mathrm{NH}_{2}$, the following procedure was used: $300 \mathrm{mg}$ of powder $\mathrm{MSNs}-\mathrm{NH}_{2}$ was added to the prepared solvent containing $100 \mathrm{mg}$ of $\mathrm{SH}$, and then EDC and NHS cross-linking were added to the mixture solution and stirred for $24 \mathrm{~h}$ at room temperature. The solvent was evaporated at $50^{\circ} \mathrm{C}$ using the Rotavapor (Büchi, Switzerland), and then re-suspended in ultra-pure water to remove unloaded molecules. This was repeated several times. After drying at $40^{\circ} \mathrm{C}$ for $12 \mathrm{~h}$ in an oven, the resulting product was denoted as MSNs- $\mathrm{NH}_{2}-\mathrm{SH}$ nanoformulation.
To prepare a combined nanoformulation, the procedure for loading with $\mathrm{SH}$ was performed first, followed by the procedure for loading with $\mathrm{QR}$. The resulting product was denoted as MSNs-NH $2-S H-Q R 1$ nanoformulation. The used materials are summarized in Table 1.

\section{Estimation of Prodrug Concentration}

The amount of prodrug in nanoformulations was determined by simultaneous thermal analysis (STA) via weight loss analysis. The STA results for the modified materials before and after loading were compared. The calculated percent of each prodrug in a nanoformulation is listed in Table 1. Hereafter, when the concentration of prodrug given in a nanoformulation is mentioned, it is the equivalent amount of prodrug used to prepare the desired concentration based on the calculated amount of each drug loaded into nanoparticles. The following equations were used to calculate the loading content based on the weight loss data from the thermogravimetric analysis: $\mathrm{SH}$ wt. $\%=\mathrm{MSNs}-\mathrm{NH}_{2}-\mathrm{SH}-\mathrm{MSNs}_{2}-\mathrm{NH}_{2}$ *100; QR wt. $\%=$ MSNs-NH 2 -QR - MSNs-NH2*100; and SH-QR wt. $\%=$ MSNs-NH $-\mathrm{SH}-\mathrm{QR}-\mathrm{MSNs}_{2}-\mathrm{NH}_{2}{ }^{*} 100$. Knowing the drug loading content, we prepared the
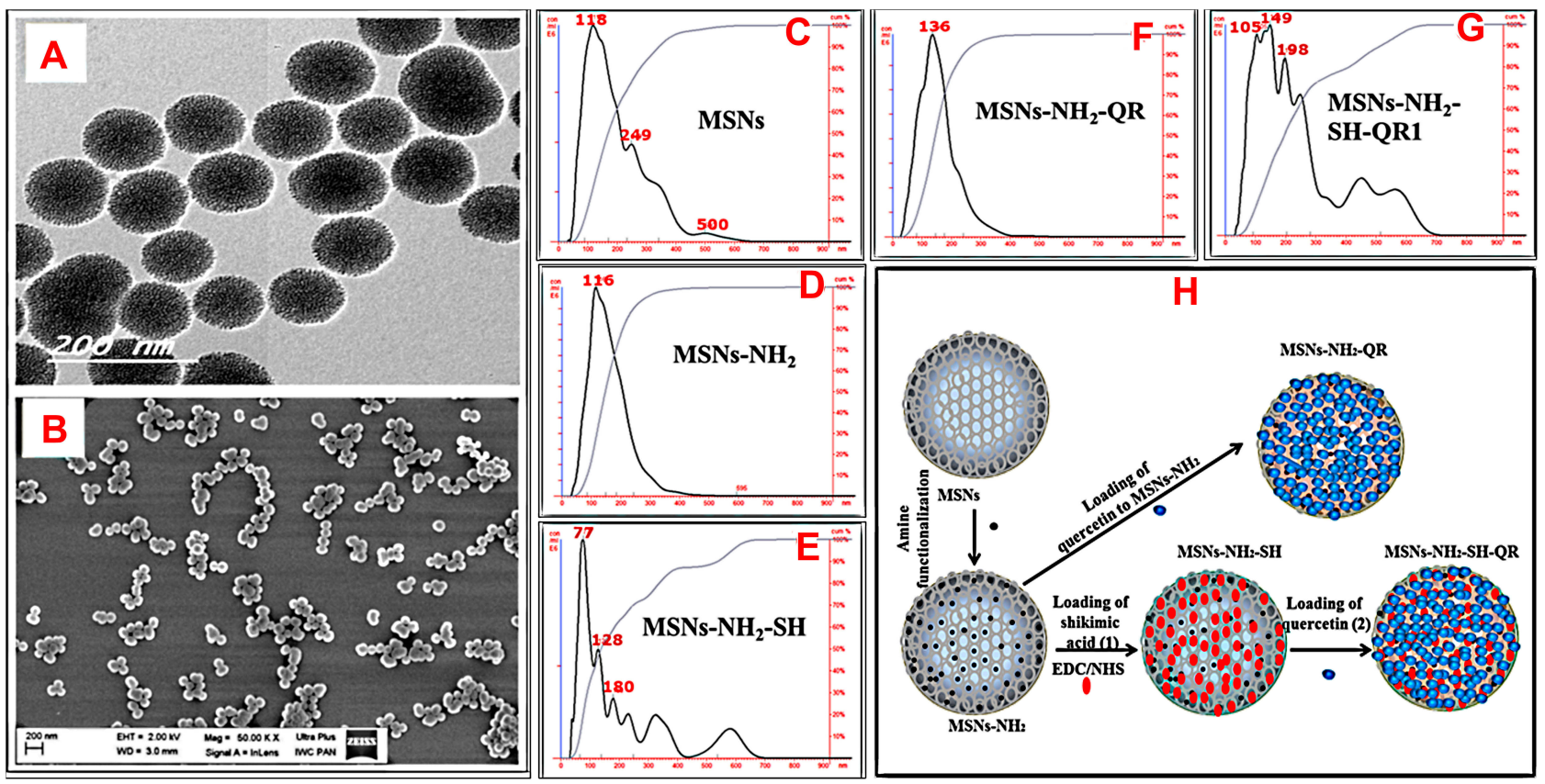

Figure I Morphological structure, size measurements, and schematic representation of preparation steps.

Notes: TEM image of nanoparticles (A), SEM image of nanoparticles (B), NTA analysis of particle size (C, D, E, F, G), and schematic representation of the synthesis method for every stage $(\mathbf{H})$.First, the nanoparticles were synthesized, then modified with amino groups $\left(-\mathrm{NH}_{2}\right)$ via a post-synthesis method. Next, prodrugs were loaded onto modified nanoparticles to obtain nanoformulations. For combined nanoformulations, we used $\mathrm{MSNs}_{\mathrm{N}} \mathrm{NH}_{2}-\mathrm{SH}$ as the starting material to load quercetin, and the resulting nanoformulation was MSNs-NH${ }_{2}-\mathrm{SH}-\mathrm{QRI}$.

Abbreviations: TEM, transmission electron microscopy; SEM, scanning electron microscopy; MSNs, mesoporous silica nanoparticles; MSNs-NH ${ }_{2}$, MSNs modified amino groups; MSNs-NH$H_{2}-\mathrm{SH}, \mathrm{MSNs}-\mathrm{NH}_{2}$ loaded $\mathrm{SH} ; \mathrm{MSNs}-\mathrm{NH}_{2}-\mathrm{QR}, \mathrm{MSNs}-\mathrm{NH}_{2}$ loaded $\mathrm{QR} ; \mathrm{MSNs}-\mathrm{NH}_{2}-\mathrm{SH}-\mathrm{QRI}, \mathrm{MSNs}-\mathrm{NH}{ }_{2}$ loaded $\mathrm{SH}$ and $\mathrm{QR} ; \mathrm{SH}$, shikimic acid; QR, quercetin. 
Table I Samples Used in the Study

\begin{tabular}{|c|c|c|c|}
\hline \multirow[t]{2}{*}{ Code of Sample } & \multicolumn{3}{|l|}{ Characteristic } \\
\hline & Prodrug Used & $\begin{array}{l}\text { Prodrug } \\
\text { Loading (\%) }\end{array}$ & Type \\
\hline MSNs & No & No & Nanoparticles (NPs) \\
\hline MSNs- $\mathrm{NH}_{2}$ & No & No & Modified nanoparticle (amino-modified NPs) \\
\hline $\mathrm{MSNs}-\mathrm{NH}_{2}-\mathrm{SH}$ & Shikimic acid & $3 \%$ & Nanoformulation \\
\hline MSNs-NH $-\mathrm{QR}$ & Quercetin & $22.4 \%$ & Nanoformulation \\
\hline MSNs-NH${ }_{2}-\mathrm{SH}-\mathrm{QRI}$ & Shikimic acid and quercetin & $24.4 \%$ & Combined nanoformulation \\
\hline MSNs-NH ${ }_{2}-\mathrm{SH}-\mathrm{QR} 2$ & shikimic acid and quercetin & $24.4 \%$ & $\begin{array}{l}\text { Combined nanoformulation. Twice higher nanoparticle } \\
\text { concentration than for MSNs-NH2-SH-QRI }\end{array}$ \\
\hline $\mathrm{SH}$ & Shikimic acid & Not relevant & Prodrug \\
\hline QR & Quercetin & Not relevant & Prodrug \\
\hline SH/QR mix.I & Simple mixture & Not relevant & Mixed prodrugs \\
\hline SH/QR mix.2 & Simple mixture & Not relevant & Mixed prodrugs \\
\hline
\end{tabular}

Notes: Nanoformulation means the prodrug(s) loaded with MSNs.

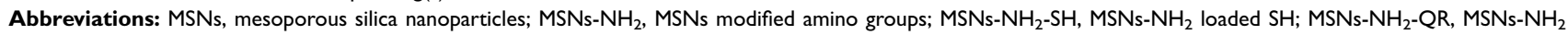
loaded QR; MSNs- $\mathrm{NH}_{2}-\mathrm{SH}-\mathrm{QRI}$, MSNs- $\mathrm{NH}_{2}$ loaded $\mathrm{SH}$ and $\mathrm{QR} ; \mathrm{MSNs}-\mathrm{NH}_{2}-\mathrm{SH}-\mathrm{QR2}$ was used in twice amount; $\mathrm{SH} / \mathrm{QR}$ mix.I, mixture of SH and QR; $\mathrm{SH} / \mathrm{QR}$ mix.2, mixture of $\mathrm{SH}$ and $\mathrm{QR}$ used in twice amount; $\mathrm{SH}$ pure, shikimic acid; $\mathrm{QR}$ pure, quercetin.

concentration from nanoformulations equal to the concentration of free prodrugs.

In the case of nanoformulations, the effective prodrug concentration was estimated as the equivalent amount of drug $(\mu \mathrm{g} / \mathrm{mL})$ in the nanoformulation from the relatedloading percent for each prodrug or in combination to prepare the stock solution(s). In the case of pure prodrugs, the calculated amount was immediately weighed, and stock solution(s) prepared. Mix 1 and mix 2 were prepared by simply mixing the weighed amount of each drug in one solution under stirring to obtain a stock solution. We calculated also the molar concentration, which is listed in $\underline{\text { Tables } \mathrm{S} 1}$ and $\underline{\mathrm{S} 2}$. These concentrations are calculated based on the used $\mu \mathrm{g} / \mathrm{mL}$ throughout the experiments.

\section{Material Characterization Techniques}

The images of prepared MSNs were observed by High Resolution Transmission Electron Microscope, HR-TEM (JEM 2100, JEOL, Tokyo, Japan), Field Emission Scanning Electron Microscope, FE-SEM (FE-SEM; Ultra Plus, Zeiss, Jena, Germany). The elemental analysis was acquired using the QUANTAX EDS (Bruker, Billerica, MA, USA)connected to FE-SEM. The sputtering of the samples for FESEM imagining was performed on sputter coater (Bal-Tech SCD 005) and/or (Q150T ES, Quorum Technologies Ltd, East Sussex, UK). The powder X-ray diffraction (X'PertPRO System, PANalytical, Marietta, GA, USA) was employed for XRD patterns. The surface area and volume properties were characterized using Gemini 2360, Micromeritics, Norcross,
GA, USA. FTIR spectra were performed using a Fourier transformed infrared (FTIR) spectroscopy (Bruker Optics, Billerica, MA, USA) equipped with an Attenuated Total Reflectance (ATR, model Platinum ATR-Einheit A 255). Simultaneous Thermal Analysis (STA)-coupled with Differential Scanning Calorimetry (DSC)-connected with FTIR analysis (STA 499 F1Jupiter, NETZSCHFeinmahltechnik GmbH, Selb, Germany) was used to determine the drug loading, crystalline state and evolved gases from the heating samples. The zeta potential (Malvern ZetaSizer, Malvern, UK) was performed to determine the type of charges on the nanoparticles in prepared suspensions. The particle size distributions were done by nanoparticle tracking analysis (NTA) with the NanoSight instrument (NS500, NanoSight, UK).

\section{Cells and Virus Used in the Study}

Madin Darby Canine kidney (MDCK) cells were cultured in Dulbecco's modified Eagle's medium (DMEM) supplemented with $10 \%$ fetal bovine serum, penicillin $(100 \mathrm{U} / \mathrm{mL})$, and streptomycin $(0.1 \mathrm{mg} / \mathrm{mL})$ and incubated at $37^{\circ} \mathrm{C}$ in a humidified atmosphere of $5 \% \mathrm{CO}_{2}$. The MDCK cells were kindly provided by Dr. Richard Webby (St. Jude Children's Research Hospital, department of virology and molecular biology, USA). Using of cell lines had ethical approval from the ethical committee at NRC, Egypt. It was supplied as a confluent sheet in a $75 \mathrm{~cm}^{2}$ tissue culture flask. These cells were propagated till confluence for several passages, harvested in aliquots, and then stored in liquid nitrogen 
till being used. An avian influenza A/duck/Egypt/Q4596D/ 2012 (H5N1) virus was propagated in MDCK cells and stored at $-80^{\circ} \mathrm{C}$ for further investigation. All experiments involving viruses were performed under Biosafety Level 3 conditions (Germfree, USA).

\section{Biocompatibility and Cytotoxicity Evaluation}

To evaluate the in vitro cell viability of the prepared nanocarriers, the MTT assay was employed according to Mosmann. ${ }^{50}$ Various concentrations of MSNs and MSNs$\mathrm{NH}_{2}$ (up to $750 \mu \mathrm{g} / \mathrm{mL}$ ) were suspended in PBS buffer. The MDCK cells $\left(1.0 \times 10^{4}\right.$ per well) were seeded in 96-well plates in DMEM medium. After $24 \mathrm{~h}$ to allow the attachment of cells under optimum conditions of $5 \% \mathrm{CO}_{2}$ and $37^{\circ}$ $\mathrm{C}$, the DMEM was aspirated from each well and the MDCK cells washed with PBS ( $\mathrm{pH}$ 7.4). Predetermined nanoparticle concentrations were added to cells in triplicate and incubated for $24 \mathrm{~h}$. The medium was then removed and the monolayer of cells washed with PBS three times before adding MTT solution ( $20 \mu \mathrm{L}$ of $5 \mathrm{mg} / \mathrm{mL}$ stock solution) to each well and incubating at $37^{\circ} \mathrm{C}$ for $4 \mathrm{~h}$. Formazan crystals were dissolved with $200 \mu \mathrm{L}$ of dimethyl sulfoxide (DMSO) and the absorbance measured at $\lambda$ max $540 \mathrm{~nm}$ using an ELIZA Microplate Reader. Finally, cytotoxicity percentages for MSNs and MSNs- $\mathrm{NH}_{2}$ were calculated.

\section{Biological Infectivity Assay}

In a 12-well tissue culture plate, MDCK cells were pretreated with $100 \mu \mathrm{L}$ of DMEM supplemented with $0.2 \%$ bovine serum albumin. The cells were infected at 0.1 multiplicity of infection (MOI) of an A/duck/Egypt/Q4596D/2012 (H5N1) virus for $1 \mathrm{~h}$ at $37^{\circ} \mathrm{C}$. Culture medium $(500 \mu \mathrm{L})$ containing the safe concentration of each tested sample was added to each well: $50 \mu \mathrm{g} / \mathrm{mL}$ for MSNs and MSNs-NH${ }_{2}$;

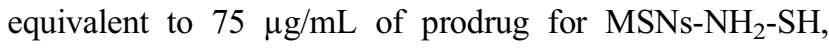

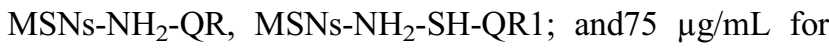
$\mathrm{SH}, \mathrm{QR}$, and mixed pure prodrugs. In the preliminary prescreening results, the combined nanoformulation MSNs$\mathrm{NH}_{2}$-SH-QR1 did not attenuate the virus. Therefore, we twice increased the concentration of MSNs- $\mathrm{NH}_{2}-\mathrm{SH}-\mathrm{QR} 1$ as equivalent to $150 \mu \mathrm{g} / \mathrm{mL}$ of prodrug inside and labeled it MSNs-NH 2 -SH-QR2. Plates were incubated at $37^{\circ} \mathrm{C}$ with $5 \% \mathrm{CO}_{2}$ for $24 \mathrm{~h}$ and $48 \mathrm{~h}$ post infection. Untreated virus was included in each plate as a control. Virus titration was assessed by measuring haemagglutinin in titers in the supernatant of infected cells in the presence and absence of tested compounds at 24 and $48 \mathrm{~h}$ post infection (hpi). Briefly, $50 \mu \mathrm{L}$ of PBS was aliquoted across a 96-well U-shaped plate
(Greiner Bio-One, Germany). Next, $50 \mu \mathrm{L}$ from infected cells was added to the first well and two-fold serial dilutions performed across the plate. Finally, $50 \mu \mathrm{L}$ of $0.5 \%$ chicken RBCs was added to all wells and the plate was shaken to ensure mixing. The plate was incubated for $30 \mathrm{~min}$ at room temperature before examining HA titer. The HA titer of the virus was calculated as the reciprocal of the highest dilution of virus that caused complete agglutination of chicken RBCs. Negative results (no agglutination) appeared as dots in the center of round-bottom plates. To calculate, the percentage of hemagglutination titer inhibition $=$ hemagglutination titer of virus control untreated - hemagglutination titer of treated virus/hemagglutination titer of virus control untreated x 100 .

To confirm the obtained results from biological assay, the new preparation of tested compounds was tested against $\mathrm{H} 5 \mathrm{~N} 1$ virus at different $\mathrm{MOI}(0.01,0.001$, and 0.0001). The cells in 96-well tissue culture plate were infected with $100 \mu \mathrm{L}$ at different MOI of an $\mathrm{A} / \mathrm{duck} /$ Egypt/Q4596D/2012 (H5N1) virus for $1 \mathrm{~h}$ at $37^{\circ} \mathrm{C}$. During incubation, in a 96-well U-shaped plate, serial dilutions of tested compounds were prepared in DMEM supplemented with $0.2 \%$ bovine serum albumin. Next, a volume of $100 \mu \mathrm{L}$ of each dilution was added to infected cells and incubated for $24 \mathrm{~h}$ post infection at a humidified incubator at $37^{\circ} \mathrm{C}$. We identified the lowest dilution of tested compound that resulted in $100 \%$ inhibition of the virus detection by HA assay.

\section{Plaque Reduction Assay and Mechanisms of Action}

The antiviral activities of tested compounds were also determined by plaque reduction assay. ${ }^{51,52}$ Briefly, MDCK cells were seeded in 6-well culture plates $\left(10^{5}\right.$ cells $\left./ \mathrm{mL}\right)$ and incubated for $24 \mathrm{~h}$ at $37^{\circ} \mathrm{C}$ in $5 \% \mathrm{CO}_{2}$. Previously titrated $\mathrm{H} 5 \mathrm{~N} 1$ virus $\left(46^{*} 10^{6} \mathrm{PFU} / \mathrm{mL}\right)$ was diluted to optimal virus dilution, which gave countable plaques, and mixed with the safe concentration (for MDCK) of each tested material. The virus was incubated for $1 \mathrm{~h}$ at $37^{\circ} \mathrm{C}$ before being added to cells. Growth medium was removed from the 6-well cell culture plates and virus-compound mixtures inoculated in duplicate. After $1 \mathrm{~h}$ contact time for virus adsorption, $3 \mathrm{~mL}$ of DMEM supplemented with $2 \%$ agarose, $1 \%$ antibiotic antimycotic mixture, and $4 \%$ bovine serum albumin (BSA, Sigma) was added to the cell monolayer. The plates were left to solidify and incubated at $37^{\circ} \mathrm{C}$ until the formation of viral plaques (3 days). Formalin (10\%) was added to each well for $1 \mathrm{~h}$ and the overlayer removed. Fixed cells were stained with $0.1 \%$ crystal violet in distilled water. Untreated virus was included in each plate as a control. Finally, 
plaques were counted and the percentage reduction in virus count recorded as follows:

$$
\begin{gathered}
\% \text { inhibition }=\text { viral count }(\text { untreated })-\text { viral count } \\
(\text { treated }) / \text { viral count }(\text { untreated }) \times 100
\end{gathered}
$$

To estimate the concentration that inhibits 50\% (IC50) of PFU for the $\mathrm{H} 5 \mathrm{~N} 1$ virus, we performed a plaque reduction assay with different equivalent concentrations of prodrug(s) as follows: 10, 25, 50, and $75 \mu \mathrm{g} / \mathrm{mL}$ for MSNs-NH2-SH, and 20, 50, 100, and $150 \mu \mathrm{g} / \mathrm{mL}$ for MSNs-NH2-SH-QR2.

The mechanism of viral replication was assayed according to Kuo et al. ${ }^{53}$ MDCK cells were cultivated in a 6-well plate $\left(10^{5} \mathrm{cell} / \mathrm{sml}\right)$ for $24 \mathrm{~h}$ at $37^{\circ} \mathrm{C}$. Virus was applied directly to the cells $\left(100 \mu \mathrm{L}\right.$ of optimal virus dilution $\left.\left(10^{-4}\right)\right)$ and incubated for 1 hat $37^{\circ} \mathrm{C}$. Non-adsorbed viral particles were removed by washing cells three successive times with supplement-free medium. The nanoformulations (MSNs$\mathrm{NH}_{2}$-SH and MSNs- $\mathrm{NH}_{2}$-SH-QR2) were added, and after $1 \mathrm{~h}$ contact time $3 \mathrm{~mL}$ of DMEM supplemented with $2 \%$ agarose was added to the cell monolayer. Plates were left to solidify and incubated at $37^{\circ} \mathrm{C}$ until the appearance of viral plaques. Cell monolayers were fixed in $10 \%$ formalin solution for $1 \mathrm{~h}$ and stained with crystal violet. Virus control wells including infected MDCK cells without treatment were included in each plate. Plaques were counted and the percentage reduction in plaque formation compared to the virus control wells.

The viral adsorption mechanism was assayed according to Zhang et $\mathrm{al}^{54}$ with minor modifications. MDCK cells were cultivated in a 6 -well plate $\left(10^{5}\right.$ cells $\left./ \mathrm{mL}\right)$ for $24 \mathrm{~h}$ at $37^{\circ} \mathrm{C}$. Each examined nanoformulation was applied in 200 $\mu \mathrm{L}$ medium without supplements and co-incubated with the cells for 2 hat $4{ }^{\circ} \mathrm{C}$. Non-absorbed nanoformulation particles were removed by washing cells three successive times with supplement-free medium, the diluted H5N1 virus was co-incubated with the pretreated cells for $1 \mathrm{~h}$, and then $3 \mathrm{~mL}$ DMEM supplemented with $2 \%$ agarose was added. Plates were left to solidify and then incubated at $37^{\circ} \mathrm{C}$ to allow the formation of viral plaques. The plaques were fixed and stained as described above to calculate the percentage reduction in plaque formation compared to virus control wells, which comprised untreated MDCK cells directly infected with H5N1.

The virucidal mechanism was assayed according to Schuhmacher et al. ${ }^{55}$ In a 6-well plate, MDCK cells were cultivated $\left(10^{5}\right.$ cells $\left./ \mathrm{mL}\right)$ for $24 \mathrm{~h}$ at $37^{\circ} \mathrm{C}$. A total volume of $200 \mu \mathrm{L}$ of serum-free DMEM containing $100 \mu \mathrm{L}$ of the optimal H5N1 virus dilution and $100 \mu \mathrm{L}$ of tested compounds was mixed. After $1 \mathrm{~h}$ incubation at room temperature, the mixture was added to pre-washed MDCK cell monolayer. After $1 \mathrm{~h}$ contact time, a DMEM overlayer was added to the cell monolayer. Plates were left to solidify and incubated at $37^{\circ} \mathrm{C}$ to allow the formation of viral plaques. The plaques were fixed and stained as described above to calculate the percentage reduction in plaque formation. This value was compared to virus control wells comprising cells infected with virus that was not pretreated with the tested material.

\section{Isolation and Culture of Splenocytes}

Splenocytes were isolated from male Swiss albino mice (8-12 weeks old) obtained from the Animal House Colony of the National Research Centre, Cairo, Egypt. Briefly, mice were euthanized by cervical dislocation; their spleens were excised and gently homogenized to obtain single-cell splenocyte suspensions using RPMI-1640 media supplemented with $10 \%(\mathrm{v} / \mathrm{v})$ heat-inactivated, fetal calf serum (FCS) $1000 \mathrm{U} / \mathrm{mL}$ penicillin and $1000 \mu \mathrm{g} / \mathrm{mL}$ streptomycin (complete medium). Red blood cells were lysed by resuspending spleen cells in ammonium chloride-lysis buffer (144 mM ammonium chloride, $17 \mathrm{mM}$ Tris, $\mathrm{pH}$ 7.2) and incubating on ice for $10 \mathrm{~min}$. Splenocytes were washed twice with phosphate-buffered saline (PBS) and then resuspended in complete medium.

\section{Cell Viability and Proliferation Assay}

The effect of prepared materials on splenocyte viability and proliferation in response to a $\mathrm{T}$ cell mitogen (phytohemagglutinin; PHA) was evaluated using the MTT assay. ${ }^{56}$ Freshly prepared splenocytes $\left(2 \times 10^{5}\right.$ cells/200 $\mu \mathrm{L} /$ well $)$ were cultured in a 96-well U-bottom microtiter plate (Nunc) in complete medium. Cells were treated in the presence or absence of a final concentration of 25, 50, or 100 $\mu \mathrm{g} / \mathrm{mL}$ of nanoparticles, equivalent prodrug concentration in nanoformulations, or pure prodrugs alone or mixed (using $0.5 \% \mathrm{DMSO}$ ) in triplicate, and then incubated at $37^{\circ} \mathrm{C}$ in a $5 \% \mathrm{CO}_{2}$ atmosphere.

To test the immunoregulatory effects on splenocyte stimulation, PHA $(5 \mu \mathrm{g} / \mathrm{mL})$ was added to the culture media to induce $\mathrm{T}$ cell proliferation for $24 \mathrm{~h}$. Nanoparticles, prodrugs alone or mixed, and an equivalent amount of drug in nanoformulation were added at $25 \mu \mathrm{g} / \mathrm{mL}$. The proliferative response to PHA+MSNs and MSNs alone served as controls. After $72 \mathrm{~h}$, the cells were pelleted and the media removed by 
centrifugation. MTT salt solution $(5 \mathrm{mg} / \mathrm{mL})$ was added to each well and incubated at $37^{\circ} \mathrm{C}$ for $4 \mathrm{~h}$. Formazan crystals were dissolved by adding $100 \mu \mathrm{L} 10 \%$ SDS before measuring absorbance at $570 \mathrm{~nm}$ in a spectrophotometer using a reference wavelength of $690 \mathrm{~nm}$. Cell viability was expressed using the following formula with optical density (OD):

$\%$ of viable cells $=(\mathrm{OD}$ of test samples $/ \mathrm{OD}$ of $\mathrm{MSNs})$ x 100

The splenocyte stimulation index was determined as the ratio of OD values in test samples versus PHA+MSNs control.

\section{Isolation of Peritoneal Macrophages}

Mice were sacrificed by cervical dislocation and the abdominal cavity lavaged aseptically with 5 mL RPMI1640 medium. The peritoneal cavity was then gently massaged and the media aspirated. Cells were precipitated by centrifugation and re-suspended in RPMI1640 medium containing $10 \%$ FCS and considered peritoneal macrophages. ${ }^{57}$

\section{Nitric Oxide and Cytokine Measurements}

To assess the immunomodulatory effect in vitro, we stimulated the mouse intraperitoneal macrophages with lipopolysaccharide (LPS), an outer membrane compound in Gramnegative bacteria that promotes the activation and cell differentiation of macrophages upon exposure. ${ }^{58,59}$ Activation by LPS resulted in increased production of pro-inflammatory factors, such as cytokines (TNF- $\alpha$ and IL-1 $\beta$ ) and NO. ${ }^{60}$ Peritoneal macrophage cell suspensions $\left(1 \times 10^{5}\right.$ cells/200 $\mu \mathrm{L})$ were plated in 96-well microplates. The cells were treated in the presence or absence of $25 \mu \mathrm{g} / \mathrm{mL}$ of prodrugs, MSNs, MSNs- $\mathrm{NH}_{2}$, or equivalent amount of prodrug in nanoformulations $(0.5 \% \mathrm{DMSO})$ in triplicate for $4 \mathrm{~h}$ before the addition of $1 \mu \mathrm{g} / \mathrm{mL}$ LPS from E. coli strain 0111:B4. After $24 \mathrm{~h}$ incubation, cell culture supernatants were collected to evaluate NO and cytokine levels. The production of NO in the supernatant was determined by measuring the quantity of nitrite by the Griess reaction, ${ }^{61}$ and TNF- $\alpha$ and IL-1 $\beta$ were detected by enzyme-linked immune sorbent assay (ELISA) according to the manufacturer's instructions.

\section{Anti-Inflammatory Activity Screening}

Anti-inflammatory activity was determined in vivo using the acute carrageenan-induced paw edema rat model ${ }^{62}$ characterized by acute accumulation of fluids and hyperalgesia in the paw-following carrageenan administration.
This model allows the anti-inflammatory potential to be assessed by quantifying changes in the size of the paw edema. The inflammation induced by carrageenan injection into animals is thought to have a biphasic process. In the early stage, histamine and serotonin are produced at high levels, peaking at $3 \mathrm{~h}$ with the release of kinin-like compounds. In the late stage, prostaglandins, proteases, and lysozymes are produced. ${ }^{63}$ Male Wistar rats weighing 150-180 g were obtained from the Animal House Colony of the National Research Centre (Cairo, Egypt) and housed under standardized conditions (room temperature $23 \pm 2^{\circ} \mathrm{C}$; relative humidity $55 \pm 5 \% ; 12 \mathrm{~h}$ light/dark cycle) with free access to tap water and standard mouse chow throughout the whole experimental period. The rats were divided into five groups of six animals each. All experimental protocols were performed in accordance with the recommendations for the proper care and use of laboratory animals following the regulations of the ethical committee of the National Research Centre (Protocol number: 16156). MSNs-NH2, MSNs-NH2-SH-QR2, SH-QR mix 2, and indomethacin were dissolved in saline at $10 \mathrm{mg} / \mathrm{kg}$ and given intraperitoneally $2 \mathrm{~h}$ before induction of inflammation. Carrageenan paw edema was induced by subcutaneous injection of a freshly prepared $1 \%$ carrageenan solution into the subplantar tissue of the right hind paw. The thickness of the paw was measured using a digital caliper at 1, 4, and $24 \mathrm{~h}$ and compared to the initial hind paw thickness of each rat to determine the edema thickness.

\section{Statistical Analysis}

Data are expressed means \pm SD of triplicates, one-way ANOVA with post hoc Fisher's least significant difference test LSD and $\mathrm{p}<0.05$ was considered significant difference.

\section{Results and Discussion Morphological and Elemental Analysis of MSNs and Nanoformulations}

The structures of the nanoparticles were in good agreement with those reported in a previous study. ${ }^{48}$ HR-TEM and FE-SEM images (Figure 1A and B) showed that the MSNs were well dispersed and had uniform nearly spherical shapes with an average diameter of $\sim 100 \mathrm{~nm}$. EDS analysis (Figure S1) confirmed the elemental content of all prepared materials. The prodrugs were organic carboncontaining compounds; therefore, the carbon percentage is a good indicator of their loading into MSNs. The carbon content changed from $5.9 \mathrm{wt}$ \% for the MSNs to $15.1 \mathrm{wt} . \%$ 
for MSNs-NH $2,15.4$ wt.\% for $\mathrm{MSNs}_{2}-\mathrm{NH}_{2}-\mathrm{SH}, 20.6 \mathrm{wt} . \%$ for MSNs- $\mathrm{NH}_{2}-\mathrm{QR} 1$, and 21.5 wt.\% for $\mathrm{MSNs}-\mathrm{NH}_{2}-\mathrm{SH}-$ QR2 (Figure S1 and Table 2). This observation reveals the successful loading of prodrugs into MSNs particles.

\section{Nanoparticle Tracking Analysis (NTA)}

The mean size was $118 \mathrm{~nm}$ (MSNs), $116 \mathrm{~nm}\left(\mathrm{MSNs}-\mathrm{NH}_{2}\right), 77$ nm (MSNs-NH $-\mathrm{SH}), 136 \mathrm{~nm}$ (MSNs-NH $2-\mathrm{QR})$, and $149 \mathrm{~nm}$ (MSNs-NH ${ }_{2}-\mathrm{SH}-\mathrm{QR} 1$ ) (Figure $1 \mathrm{C}-\mathrm{G}$ and Table 2). For MSNs- $\mathrm{NH}_{2}-\mathrm{SH}-\mathrm{QR} 2$, the only difference was twice the amount of MSNs-NH$-\mathrm{NH}_{2}-\mathrm{SH}-\mathrm{QR} 1$ and, therefore, it is not mentioned in characterizations. The reduction in size for MSNs$\mathrm{NH}_{2}-\mathrm{SH}$ is an unexpected observation but could be due to some surface reactions. As expected, the size of $\mathrm{MSNs}-\mathrm{NH}_{2}$ gradually increased after loading, which may indicate some segregation of the prodrug on the surface or be due to low drug loading.

\section{Nitrogen Sorption Measurements}

As expected, loading of prodrugs was accompanied by a reduction in the specific surface area because the nanopores are filled with prodrug molecules (Table 2). The high specific surface $\left(400 \mathrm{~m}^{2} / \mathrm{g}\right)$ of MSNs was reduced to $71.2 \mathrm{~m}^{2} / \mathrm{g}$ $\left(\mathrm{MSNs}-\mathrm{NH}_{2}\right), \quad 64.8 \quad \mathrm{~m}^{2} / \mathrm{g} \quad\left(\mathrm{MSNs}-\mathrm{NH}_{2}-\mathrm{SH}\right), 13.2 \quad \mathrm{~m}^{2} / \mathrm{g}$ (MSNs-NH $-\mathrm{QR}$ ), and $12.1 \mathrm{~m}^{2} / \mathrm{g}$ for (MSNs-NH$-\mathrm{SH}-\mathrm{QR}$ ). Both surface modification and loading of drugs on MSNs reduced the surface area and pore volume characteristics as reported previously in several studies. ${ }^{49,64-67}$

\section{XRD and DSC Analysis}

In the case of prodrugs loaded in the nanopores of amorphous silica, one would expect them to take on an amorphous structure similar to the host. For molecules on the surface, without constraint of the host material, they may take on a crystalline structure. As seen from the XRD patterns (Figure 2A), after loading of $\mathrm{SH}$ on MSNs, no peaks corresponding to $\mathrm{SH}$ were detected, which may indicate low loading of this prodrug. In contrast, several small peaks were detected for the loading of $\mathrm{QR}$ alone or in combination, which may indicate that some $\mathrm{QR}$ molecules remain on the exterior surface of the nanoparticles and crystalize. As the detected peaks are small, it seems that only a negligible amount of prodrug crystalized on the MSN surface. The simple physical mixing of prodrugs and MSNs resulted in high-intensity peaks corresponding to prodrugs not embedded in the nanopores.

The DSC plots (Figure 2B) show that, for loaded drugs, there were no endothermic peaks at the melting temperatures compared to $\mathrm{SH}\left(175^{\circ} \mathrm{C}\right)$ and $\mathrm{QR}\left(320^{\circ} \mathrm{C}\right)$. This observation confirms that most of the loaded prodrug is situated in the nanopores, and this confinement restricts their crystallization (Figure 2A). The DSC results in our study are consistent with other reports showing the potential to suppress the crystallization of amorphous drugs by enclosing them in MSNs. ${ }^{68,69}$ The DSC plots show some exothermic peaks at $290^{\circ} \mathrm{C}$, which decrease as the prodrug loading increases. This may correspond to some surface reactions of the modified nanoparticles. For nanoformulations, a shoulder is seen at approximately $400^{\circ} \mathrm{C}$, which may correspond to the gradual decomposition of the prodrug.

\section{Simultaneous Thermal Analysis}

To further quantify the amount of prodrug loaded onto MSNs, we performed STA. We calculated the \%wt. of -

Table 2 Physico-Chemical Characteristics of Nanoparticles, Modified Nanoparticles, Nanoformulations, and Combined Nanoformulations

\begin{tabular}{|c|c|c|c|c|c|c|}
\hline \multirow[t]{2}{*}{ Sample } & \multirow[t]{2}{*}{$S_{B E T}\left(m^{2} / g\right)$} & \multirow{2}{*}{$\begin{array}{l}\text { Pore } \\
\text { Volume } \\
\left(\mathrm{cm}^{3} / \mathrm{g}\right)\end{array}$} & \multirow{2}{*}{$\begin{array}{l}\text { Mean size Distribution } \\
(\mathrm{nm})\end{array}$} & \multicolumn{2}{|c|}{ Elemental Analysis $^{c}$} & \multirow{2}{*}{$\begin{array}{l}\text { Loading Content } \\
(w t . \%)^{d}\end{array}$} \\
\hline & & & & $\mathbf{C} \%$ & N\% & \\
\hline MSNs & 400 & 1.29 & $230 \pm 15.2$ & 5.89 & - & - \\
\hline MSNs-NH ${ }_{2}$ & 71.2 & 0.95 & $174 \pm 4.6$ & 15.06 & 2.93 & - \\
\hline $\mathrm{MSNs}-\mathrm{NH}_{2}-\mathrm{SH}$ & 64.8 & 0.63 & $211 \pm 19.6$ & 15.36 & 2.95 & 3 \\
\hline MSNs-NH ${ }_{2}-\mathrm{QR}$ & 13.2 & 0.36 & $145 \pm 6.1$ & 20.59 & 2.43 & 22.4 \\
\hline $\mathrm{MSNs}-\mathrm{NH}_{2}-\mathrm{SH}-\mathrm{QR}$ & 12.1 & 0.27 & $236 \pm 18.8$ & 21.46 & 2.21 & 24.4 \\
\hline
\end{tabular}

Notes: ${ }^{a}$ Pore volume from nitrogen adsorption measurements; ${ }^{b}$ mean size distribution measurements by means of NTA; ${ }^{c}$ amount of $\mathrm{C}$ and $\mathrm{N}$ was calculated from the elemental analysis by EDS. 'Drug loading content was calculated by means of weight loss from thermogravimetric analysis: $\mathrm{SH}$ wt.\%=MSNs- $\mathrm{NH} \mathrm{H}_{2}-\mathrm{SH}-\mathrm{MSNs}^{\mathrm{N}} \mathrm{NH}{ }_{2}{ }^{*} \mathrm{I00}$; $\mathrm{QR}$ wt. $\%=\mathrm{MSNs}-\mathrm{NH}_{2}-\mathrm{QR}-\mathrm{MSNs}-\mathrm{NH} 2 * 100 ;$ and $\mathrm{SH}-\mathrm{QR}$ wt.\% $=\mathrm{MSNs}-\mathrm{NH}_{2}-\mathrm{SH}-\mathrm{QR}-\mathrm{MSNs}-\mathrm{NH}_{2} * 100$.

Abbreviations: ${ }^{\mathrm{S}} \mathrm{BET}$, specific surface area measured by Brunauer-Emmett-Teller; EDS, energy dispersive $\mathrm{X}$-Ray spectroscopy; NTA, nanoparticle tracking analysis; MSNs, mesoporous silica nanoparticles; $\mathrm{MSNs}-\mathrm{NH}_{2}$, MSNs modified amino groups; $\mathrm{MSNs}-\mathrm{NH}_{2}-\mathrm{SH}, \mathrm{MSNs}-\mathrm{NH}_{2}$ loaded $\mathrm{SH} ; \mathrm{MSNs}-\mathrm{NH} \mathrm{H}_{2}-\mathrm{QR}, \mathrm{MSNs}-\mathrm{NH}{ }_{2}$ loaded QR; $\mathrm{MSNs}-\mathrm{NH}_{2}-\mathrm{SH}$ $\mathrm{QR}, \mathrm{MSNs}-\mathrm{NH}_{2}$ loaded $\mathrm{SH}$ and $\mathrm{QR} ; \mathrm{SH}$, shikimic acid; $\mathrm{QR}$, quercetin. 

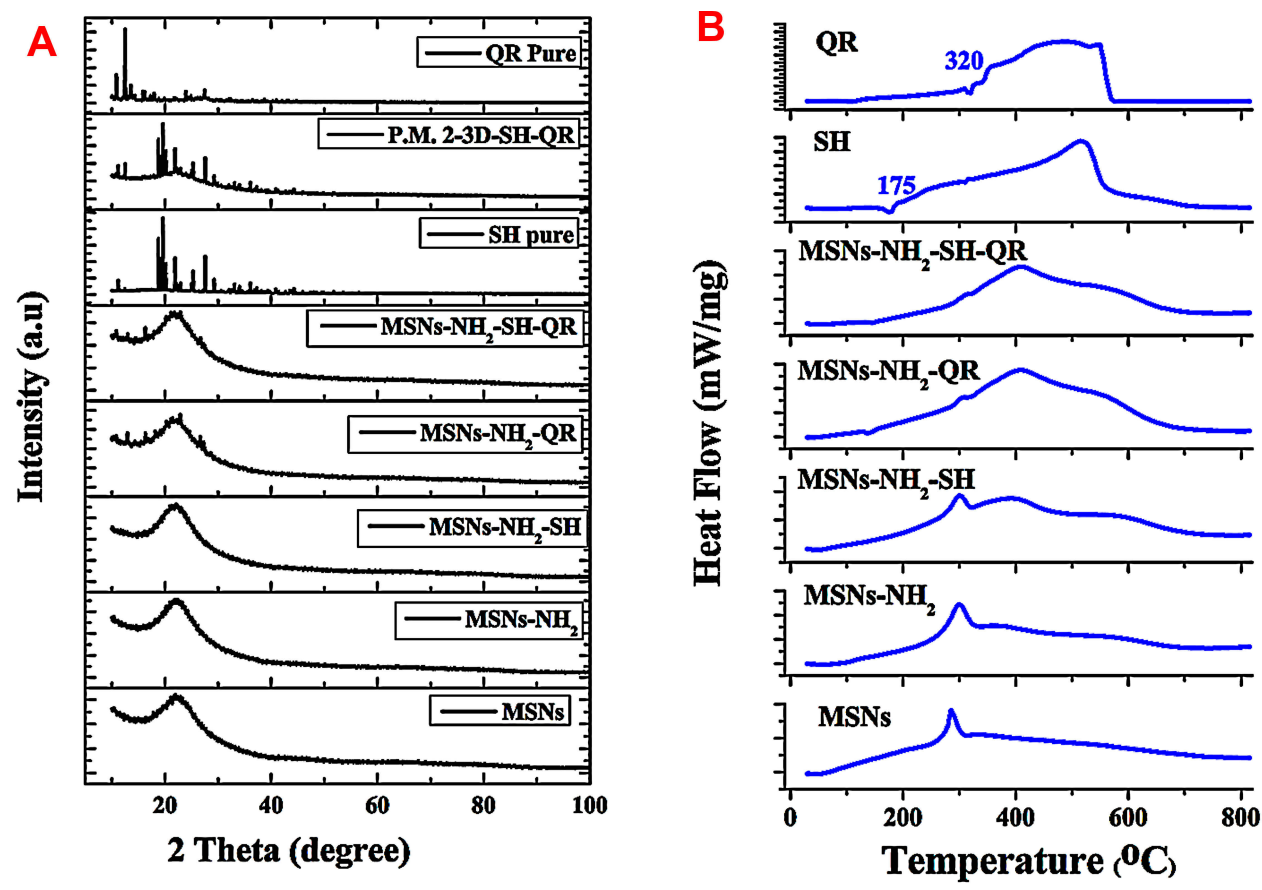

Figure $2 \times R D$ and DSC measurements.

Notes: XRD patterns of all prepared materials. Starting from the bottom: nanoparticles, modified nanoparticles, nanoformulations, combined nanoformulations, and pure prodrugs (A).DSC spectra obtained for materials. Starting from the bottom: nanoparticles, modified nanoparticles, nanoformulations, combined nanoformulations, and pure prodrugs (B).

Abbreviations: XRD, X-ray powder diffraction; DSC, differential scanning calorimetry analysis; P.M. 2-3D - SH-QR is a physical mixture of prodrugs and MSNs; MSNs, mesoporous silica nanoparticles; $\mathrm{MSNs}-\mathrm{NH}_{2}$, MSNs modified amino groups; $M S N s-\mathrm{NH}_{2}-\mathrm{SH}, \mathrm{MSNs}-\mathrm{NH}_{2}$ loaded SH; $\mathrm{MSNs}-\mathrm{NH}_{2}-\mathrm{QR}, \mathrm{MSNs}-\mathrm{NH}_{2}$ loaded QR; $\mathrm{MSNs}-\mathrm{NH}_{2}-\mathrm{SH}$ $-\mathrm{QR}, \mathrm{MSNs}-\mathrm{NH}_{2}$ loaded $\mathrm{SH}$ and $\mathrm{QR} ; \mathrm{SH}$, shikimic acid; QR, quercetin.

$\mathrm{NH}_{2}$ and the amount of prodrug based on weight loss (Figure 3A and Table 2). The amount of aminopropyl$\mathrm{NH} 2$ was $10.15 \mathrm{wt} \%$, indicating successful functionalization of nanoparticles with aminopropyl groups. The loading percentages were $3 \mathrm{wt} \%$ for $\mathrm{MSNs}-\mathrm{NH}_{2}-\mathrm{SH}$, 22.45 wt.\% for MSNs- $\mathrm{NH}_{2}-\mathrm{QR}$, and $24.41 \mathrm{wt} \%$ for MSNs$\mathrm{NH}_{2}-\mathrm{SH}-\mathrm{QR}$. These results give clear evidence that the MSNs are suitable for encapsulating two or more drugs. The same type of the MSNs showed high loading capacity of prodrug of thymoquinone as drug delivery system for brain cancers. $^{32}$

\section{FTIR Characterization}

The functional groups detected by Fourier transmission infrared spectroscopy (FT-IR) are shown in Figure 3B. The siliceous framework is represented by the peaks observed at $1075,960,805$, and $450 \mathrm{~cm}^{-1}$, in agreement with previous reports. ${ }^{70,71}$ Modification by amino groups in MSNs- $\mathrm{NH}_{2}$ leads to new peaks at 730 and $692 \mathrm{~cm}^{-1}$. Peaks at 1558 and $1486 \mathrm{~cm}^{-1}$ correspond to the $-\mathrm{NH}_{2}$ asymmetric bending $^{72}$ and $\mathrm{C}-\mathrm{H}$ asymmetric and symmetric bending vibrations, ${ }^{64}$ respectively. However, low loading of $\mathrm{SH}$
(MSNs- $\mathrm{NH}_{2}-\mathrm{SH}$ ) leads to the appearance of the $948 \mathrm{~cm}^{-1}$ band. In the case of $\mathrm{QR}$ alone (MSNs-NH$-\mathrm{QR})$ or in combination (MSNs- $\mathrm{NH}_{2}-\mathrm{SH}-\mathrm{QR}$ ), several peaks were observed corresponding to QR. As a comparison, the spectra of $\mathrm{SH}$ and $\mathrm{QR}$ are presented in Figure S2. The results demonstrate successful loading with QR. The FTIR results of some peaks, as well as the XRD spectra, indicate that some QR remains on the surface of nanoparticles.

\section{STA-FTIR Analysis}

As mentioned, our prodrugs are organic substances, and during decomposition of such organic compounds $\mathrm{CO}_{2}$ is the main gas evolved. As illustrated in Figure S3, STAFTIR showed that the intensity of the $\mathrm{CO}_{2}$ peak $\left(2200 \mathrm{~cm}^{-1}\right)$ at $320^{\circ} \mathrm{C}$ was 0.14 absorbance units (AU) for MSNs. MSNs-NH$H_{2}$ had an intensity of0.15 AU of $\mathrm{CO}_{2}$ at a similar temperature $\left(320^{\circ} \mathrm{C}\right)$. For $\mathrm{MSNs}-\mathrm{NH}_{2}-\mathrm{SH}$, the $\mathrm{CO}_{2}$ peak had similar AU as $\mathrm{MSNs}-\mathrm{NH}_{2}$, which could be explained by the fact that $\mathrm{SH}$ loading was small $(3 \mathrm{wt} \%)$. A shift in $\mathrm{CO}_{2}$ evaporation to approximately $410^{\circ} \mathrm{C}$ was observed. For MSNs-NH $2-\mathrm{QR}$ or $\mathrm{MSNs}-\mathrm{NH}_{2}-\mathrm{SH}-\mathrm{QR}$, the $\mathrm{CO}_{2}$ peaks were characterized by 0.29 and $0.49 \mathrm{AU}$ at 

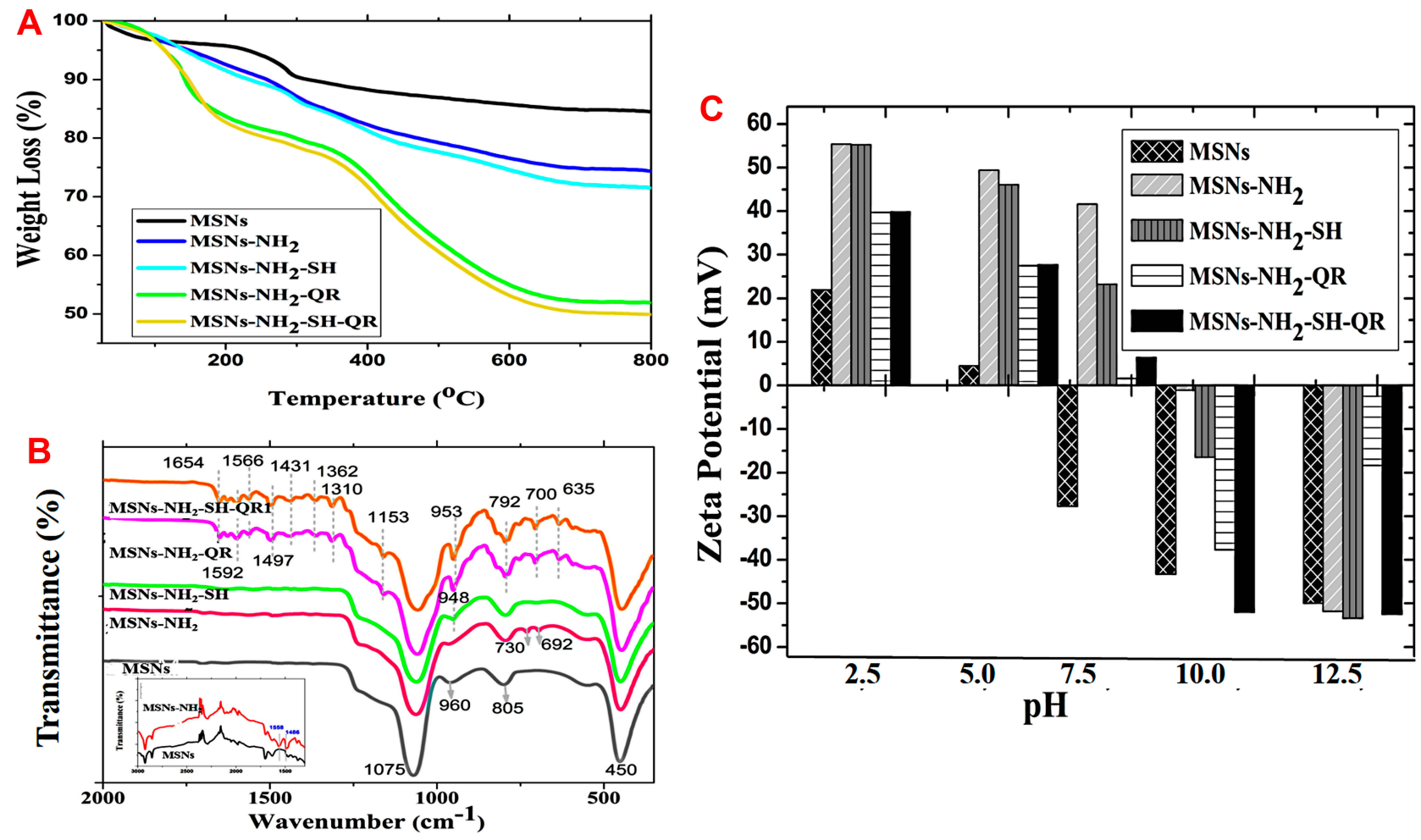

Figure 3 STA, FTIR, and zeta potential measurements.

Notes: STA analysis of nanoparticles, modified nanoparticles, nanoformulations, and combined nanoformulations (A). The thermal analysis of the dried powders was employed to detect the weight loss from materials (nanoparticles and prodrugs) at high-temperature condition. The dried powder of each sample was heated up to $800^{\circ} \mathrm{C}$ leading to lose water content, organic compounds used in surface modification and loaded prodrugs. The MSNs are inorganic material which is stable at high temperaturethis help to calculate the drug loading amount. The drug loading \% in nanoformulations was calculated based on the weight loss between modified nanoparticles and after loading into nanoformulations. FTIR spectra of nanoparticles, modified nanoparticles, nanoformulations, combined nanoformulations, and pure prodrugs (B). Zeta potential measurements of materials in aqueous suspensions from acidic to alkaline (C).

Abbreviations: STA, simultaneous thermal analysis; FTIR, Fourier transform infrared spectroscopy; MSNs, mesoporous silica nanoparticles; MSNs-NH${ }_{2}$, MSNs modified

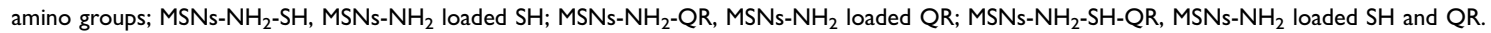

$410^{\circ} \mathrm{C}$. Generally, the loading of prodrugs onto MSNs led to a shift in the temperature, which may correspond to the decomposition of the prodrugs.

\section{Surface Charge Properties of \\ Nanoparticles and Nanoformulations}

The surface charge property of MSMs, $\mathrm{MSNs}-\mathrm{NH}_{2}$, and nanoformulations in aqueous solution is illustrated in Figure 3C. All samples had a positive zeta potential when exposed to an acidic $\mathrm{pH}$ from 2.5 to 5 . With further increasing acidity towards the physiological $\mathrm{pH}$ (7.5), a low positive zeta potential was observed. This could be attributed to abundant silanol groups on nanoparticles. At $\mathrm{pH} 7.5$, they became deprotonated and exhibited negative zeta potential, in agreement with previous results. ${ }^{73}$ An exception was the nanoparticles, which had negative zeta potential as expected. Further increasing $\mathrm{pH}$ towards alkaline $\mathrm{pH}$ at 10 and 12.5) led to negative zeta potential. The highest negative zeta value was recorded for MSNs- $\mathrm{NH}_{2}-\mathrm{SH}-\mathrm{QR}$ $(-52.5 \mathrm{mV})$ at $\mathrm{pH} 10$ and for MSNs-NH $\mathrm{N}_{2}-\mathrm{SH}-\mathrm{QR}$ and MSNs- $\mathrm{NH}_{2}-\mathrm{SH}(-52.8 \mathrm{mV})$ at $\mathrm{pH} 12.5$. Up to a $\mathrm{pH}$ of 8 , we observed modification of nanoparticles increasing the potential, with the addition of SH having no effect on the potential and loading with QR decreasing the potential. The data are in agreement with previous results for MSNs functionalized and loaded with drug molecules. ${ }^{74,75}$

\section{Antiviral Evaluations \\ Cytotoxicity Screening Studies}

When exploring any antiviral therapy, the toxic effect of the used compounds/materials should be taken into consideration. Therefore, we evaluated the cytotoxicity of the MSNs and $\mathrm{MSNs}-\mathrm{NH}_{2}$, all nanoformulations, and pure prodrugs. MSNs and MSNs- $\mathrm{NH}_{2}$ were almost not toxic for MCKD cells up to a nanoparticle dose of $50 \mu \mathrm{g} / \mathrm{mL}$ (Figure $4 \mathrm{~A}$ ). The toxic effect was dose-dependent, which is in agreement with a recent study. ${ }^{76}$ A $500 \mu \mathrm{g} / \mathrm{mL}$ nanoparticle dose resulted in 

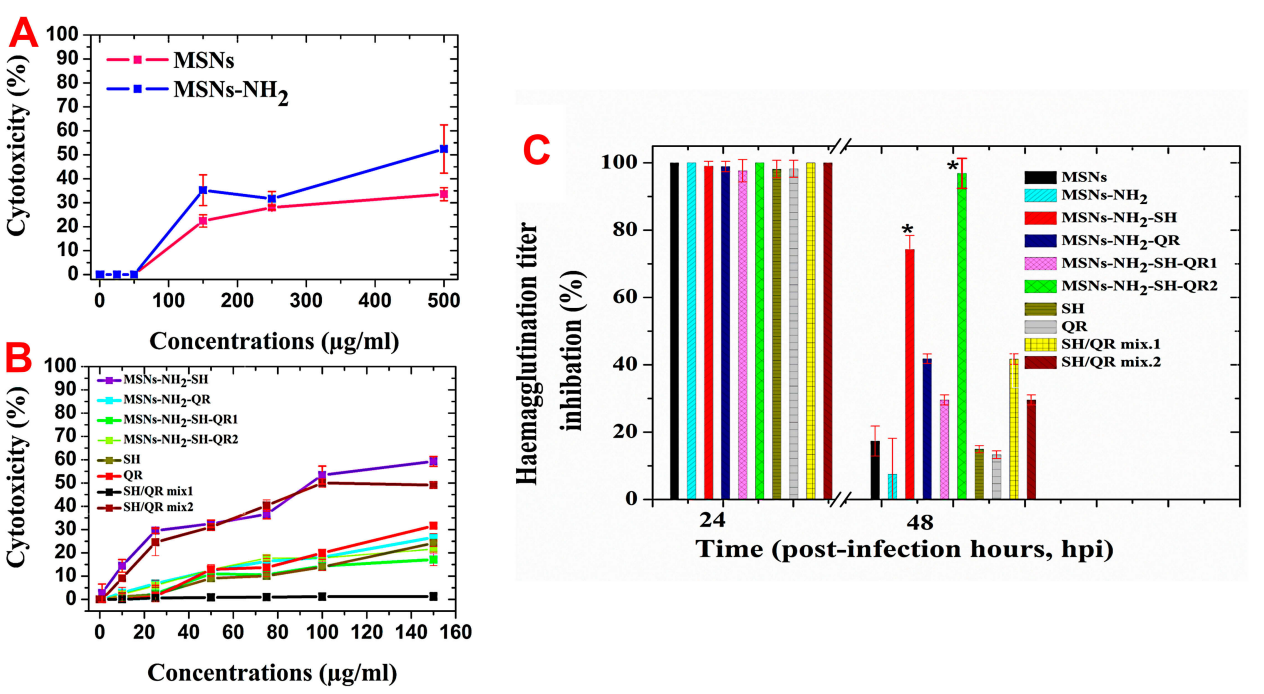

Figure 4 Cytotoxicity of materials tested for cell viability by MTT assay in MDCK cells.

Notes: As a function of nanoparticle and modified nanoparticle concentrations (A). As a function of prodrug and nanoformulation concentrations equal to pure prodrugs used alone (B). SH/QR mix2 (pure prodrug mixture) and MSNs- $\mathrm{NH}_{2}-\mathrm{SH}-\mathrm{QR} 2$ are the same materials as SH/QR mixl and MSNs-NH $\mathrm{N}_{2}-\mathrm{SH}-\mathrm{QRI}$ but twice the amount - see Table I. Antiviral activity against H5NI virus (C). The safe concentration (equivalent to $75 \mu \mathrm{g} / \mathrm{mL}$ of free compound or found in nanoformulations) was used for all materials. The safe concentration used for unmodified and modified nanoparticles was $50 \mu \mathrm{g} / \mathrm{mL}$. Data are presented as mean $\pm \mathrm{SD}$. $*$ Means significant differences at $\mathrm{P}<0.05$. The concentration for MSNs and MSNs- $\mathrm{NH}_{2}$ was directly made of prepared powder of both nanoparticles. The concentration used in nanoformulations of $\mathrm{MSNs}-\mathrm{NH}_{2}-\mathrm{SH}$, $\mathrm{MSNs}-\mathrm{NH}_{2}-\mathrm{QR}, \mathrm{MSNs}-\mathrm{NH}_{2}-\mathrm{SH}-\mathrm{QR}$, and $\mathrm{MSNs}-\mathrm{NH}_{2}-\mathrm{SH}-\mathrm{QR} 2$ was calculated based on the prodrug loaded into nanoparticles as an equivalent to free prodrugs ( $\mathrm{SH}$, QR, $\mathrm{SH} / \mathrm{QR}$ mixl, and SH/QR mix). The free prodrug concentration was normally made from the powder of pure prodrugs without any calculation.

Abbreviations: MTT, cell proliferation assay; MDCK, Madin-Darby Canine Kidney cells; MSNs, mesoporous silica nanoparticles; MSNs-NH${ }_{2}$, MSNs modified amino groups; MSNs- $\mathrm{NH}_{2}-\mathrm{SH}$, MSNs-NH$H_{2}$ loaded $\mathrm{SH} ; \mathrm{MSNs}-\mathrm{NH}_{2}-\mathrm{QR}, \quad \mathrm{MSNs}-\mathrm{NH}_{2}$ loaded $\mathrm{QR} ; \mathrm{MSNs}-\mathrm{NH}_{2}-\mathrm{SH}-\mathrm{QRI}, \mathrm{MSNs}-\mathrm{NH}_{2}$ loaded $\mathrm{SH}$ and QR; $\mathrm{MSNs}-\mathrm{NH}_{2}-\mathrm{SH}-$ $\mathrm{QR2}$ was used in twice amount; SH/QR mix.I, mixture of SH and QR; SH/QR mix.2, mixture of SH and QR used in twice amount; SH pure, shikimic acid; QR pure, quercetin; SD, standard deviation.

cytotoxicity of $33.5 \pm 2.7 \%$ for $\mathrm{MSNs}$ and $52.4 \pm 10.1 \%$ for MSNs-NH $\mathrm{N}_{2}$. Compared to MSNs, MSNs-NH $\mathrm{N}_{2}$ decreased the viability of MCDK cells. We selected $50 \mu \mathrm{g} / \mathrm{mL}$ as a safe concentration for nanoparticles (MSNs and MSNs$\mathrm{NH}_{2}$ ) in subsequent antiviral experiments because of the principle of antiviral assays that the tested compound should not inhibit $50 \%$ of host cells. For nanoformulations and prodrugs (Figure 4B), the cytotoxicity depended on the prodrug used. At a concentration of $150 \mu \mathrm{g} / \mathrm{mL}$ of prodrug, or equivalent amount of prodrug in nanoformulation, moderate toxicity was detected for MSNs-NH2-SH ( $65 \%)$, which may be due to low loading content and SH/QRmix2 $(\sim 50 \%)$. At a concentration of $75 \mu \mathrm{g} / \mathrm{mL}$, none of the tested samples decrease the cell viability to $50 \%$ or less. Therefore, for further studies, we selected the safe concentration of 75 $\mu \mathrm{g} / \mathrm{mL}$ for prodrugs or equivalent amount in nanoformulations (the exception was MSNs-NH2-SH-QR2 contained 150 $\mu \mathrm{g} / \mathrm{mL}$ ) for subsequent antiviral studies.

\section{Inhibition of H5NI Virus Titers Using Nanoformulations in vitro}

The percentage reduction in the hemagglutination titer of all samples is shown in Figure $4 \mathrm{C}$ based on the percentage of reduction in virus control (no treatment). After 24 hpi, all tested samples exhibited full virus titer inhibition and no significant differences were found among them. Increasing the incubation time of infected cells and tested compounds resulted in a reduction of virus titer. For nanoparticles, MSNs and MSNs- $\mathrm{NH}_{2}$ inhibited virus titers to $17 \%$ and $7 \%$, respectively. SH and QR exhibited weak titer inhibition equal to $14 \%$ and $15 \%$, respectively. The mixed prodrugs exhibited higher titer inhibition than separate prodrugs: SH/QR mix.2 (28\%) and SH/QR mix.1 (42\%). For nanoformulations, MSNs-NH2SH-QR2 exhibited nearly full inhibition of titers ( $\sim 98 \%)$, and MSNs- $\mathrm{NH}_{2}-\mathrm{SH}$ had a high inhibition effect of approximately 75\%. MSNs-NH $2-\mathrm{QR}$ had a moderate effect of approximately $40 \%$. Interestingly, MSNs-NH $2-\mathrm{SH}-\mathrm{QR} 2$ had a strong effect (98\% strong inhibition) compared to MSNs-NH2-SH-QR1. This effect is not attributable to prodrug action because the prodrug content is high, but to the amount of nanoparticles. Twice the amount of nanoparticles (the particles loaded with prodrug) leads to a twice stronger inhibition effect, as more nanoparticles are available to interact with virus in their inhibition. In contrast, doubling the SH-QR mixed prodrug concentration did not lead to a double inhibition effect. This observation shows the importance of using nanostructures 
for virus inhibition. The results hint at enhancing the interaction of objects of similar size (eg, nanoparticles and H5N1 virus, $\sim 100 \mathrm{~nm}$ ). Therefore, treatment of viral infections with nanoparticles should be different from that of cancer cells and bacteria, as they are micro-size and nanoparticles are simply drug carriers. In addition, only $\mathrm{MSNs}_{-} \mathrm{NH}_{2}-\mathrm{SH}-\mathrm{QR} 2$ and MSNs- $\mathrm{NH}_{2}-\mathrm{SH}$ nanoformulations exhibited a significant effect $(\mathrm{p}<0.05)$ compared to others, even 48 hpi. Therefore, the nanoformulations have the advantage of high inhibition of $\mathrm{H} 5 \mathrm{~N} 1$ virus for a long period after interaction. To confirm the obtained results, we tested the newly prepared compounds at different concentrations against different MOI of $\mathrm{H} 5 \mathrm{~N} 1$ virus. The results indicated that $\mathrm{MSNs}-\mathrm{NH}_{2}-\mathrm{SH}$ nanoformulation exhibited full virus inhibition at concentrations ranged from 75 to $18.75 \mu \mathrm{g} / \mathrm{mL}$ at $\mathrm{MOI}=0.01$ while at $\mathrm{MOI}=0.001$ and 0.0001 , it showed full inhibition till $9.3 \mu \mathrm{g} / \mathrm{mL} . \mathrm{MSNs}_{-} \mathrm{NH}_{2}-$ SH-QR2nanoformulation exhibited full inhibition of the $\mathrm{H} 5 \mathrm{~N} 1$ virus infection at concentration 150 and $75 \mu \mathrm{g} / \mathrm{mL}$ at different MOIs.

Notably, the difference in nanoformulation effects compared to prodrugs appeared 48 hpi only. This may be related to the nature of virus cycle events (ie, division and rapid replication of influenza virus), which is time dependent. These events occur between 24 and $48 \mathrm{hpi}^{77}$ and viruses produce several proteins for the replication process between 24 and 30 hpi. Thus, the prodrugs act efficiently during this period. Our results are in line with previous data related to the time effect and titer reduction. ${ }^{78}$ The strong activity of nanoformulations compared to nanoparticles and prodrugs was observed. Therefore, this approach by combining nanoparticles with drugs can be required compared to the common strategy that is followed by a combination of multiple antiviral drugs since it can be resulted in adverse drug reactions, and careful limitations should be taken into account. ${ }^{79}$ Furthermore, based on the virucidal effect discussed in the following sections, inactivating the virus structure can be affected through virion protein capsid destring its genome. So far, the viral particle integrity could also be affected.

\section{Inhibition of H5NI Virus Plaque Formation During in vitro Tests with Nanoformulations}

To further evaluate the antiviral action of the tested nanoformulations, we employed the plaque reduction assay, which is accepted as the gold standard for antiviral studies of viruses, such as influenza virus $A{ }^{80}$ The plaque formation units (PFU) of H5N1for the infected MDCK cells in the presence of the used nanoparticles, prodrugs, and nanoformulations are shown in Figure 5A. MSNs inhibited 32 $\pm 2 \%$ PFU 24 hpi compared to $16.6 \pm 1.15 \%$ by MSNs-NH 2 . Both can be considered non-significant effects. The difference in action of both nanoparticles is in agreement with recently published data in which the viral inhibition effect is associated with the interaction of virus with nanoparticles and the surface properties of silica nanoparticles. ${ }^{27}$ The difference in surface charge of nanoparticles seems to be the reason for the obtained differences. At physiological $\mathrm{pH}$
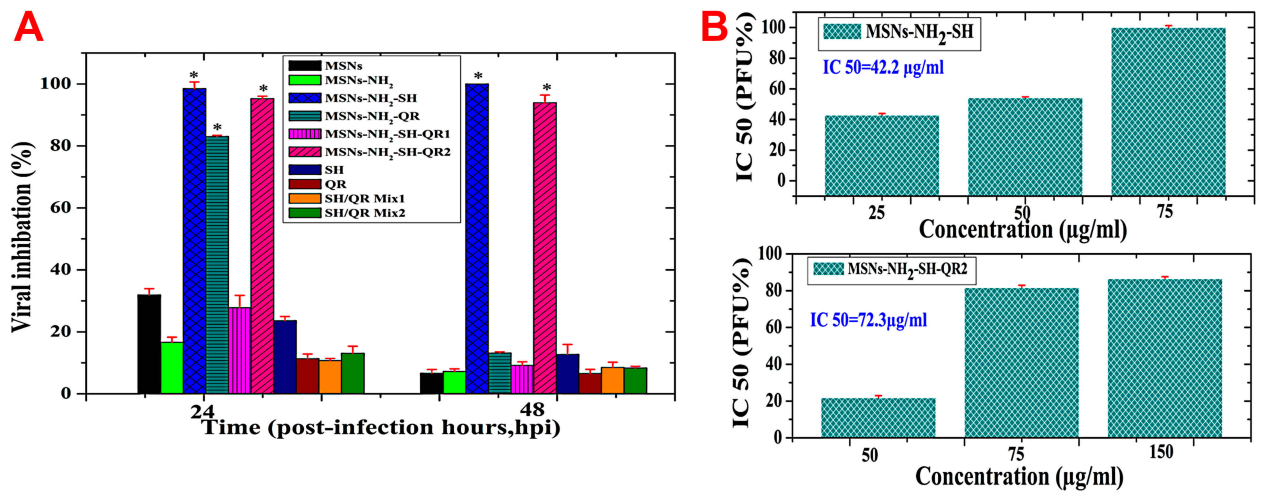

Figure 5 Plaque reduction assay used to evaluate antiviral activity against $\mathrm{H} 5 \mathrm{NI}$ virus using MDCK cells.

Notes: Nanoparticles, modified nanoparticles, prodrugs and their mixtures, nanoformulations, and combined nanoformulations with different post-time infection (A). The safe concentration (equivalent to $75 \mu \mathrm{g} / \mathrm{mL}$ of free compound or found in nanoformulations) was used for all materials. The safe concentration used for unmodified and modified nanoparticles was $50 \mu \mathrm{g} / \mathrm{mL}$.IC50 for successful nanoformulations (B). a) $\mathrm{MSNs}-\mathrm{NH}_{2}-\mathrm{SH}$ at 25,50 , and $75 \mu \mathrm{g} / \mathrm{mL}$. b) $\mathrm{MSNs}-\mathrm{NH} \mathrm{H}_{2}-\mathrm{SH}-\mathrm{QR2}$ at 50,75 , and I50 $\mu \mathrm{g} / \mathrm{mL}$. Data are presented as mean \pm SD. * Means significant differences at $\mathrm{p}<0.05$. The concentration for MSNs and MSNs-NH $\mathrm{M}_{2}$ was directly made of prepared powder of both nanoparticles. The concentration used in nanoformulations of $\mathrm{MSNs}-\mathrm{NH}_{2}-\mathrm{SH}, \mathrm{MSNs}-\mathrm{NH}_{2}-\mathrm{QR}, \mathrm{MSNs}-\mathrm{NH}{ }_{2}-\mathrm{SH}-\mathrm{QR}$, and $\mathrm{MSNs}-\mathrm{NH} \mathrm{H}_{2}-\mathrm{SH}-\mathrm{QR} 2$ was calculated based on the prodrug loaded into nanoparticles as an equivalent to free prodrugs ( $\mathrm{SH}, \mathrm{QR}, \mathrm{SH} / \mathrm{QR}$ mixl, and $\mathrm{SH} / \mathrm{QR}$ mix). The free prodrug concentration was normally made from the powder of pure prodrugs without any calculation.

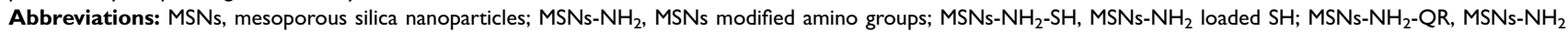

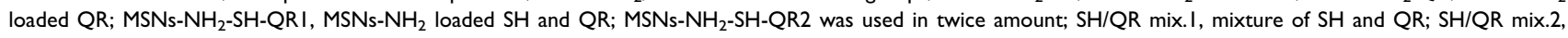
mixture of $\mathrm{SH}$ and $\mathrm{QR}$ used in twice amount; $\mathrm{SH}$ pure, shikimic acid; QR pure, quercetin; IC50, the half-maximal inhibitory concentration; SD, standard deviation. 
7.4 (Figure 3C), MSNs have a negative charge compared to the positive charge of MSNs-NH$H_{2}$. This may lead to an electrostatic interaction between negative MSNs and positive amino acids of glycoproteins in the viral envelope, followed by a charge transfer between them. ${ }^{26}$

For prodrugs, weaker effects were obtained. The percentage inhibition of virus titer was $24 \%$ for $\mathrm{SH}, 12 \%$ for $\mathrm{QR}$, $11 \%$ for $\mathrm{SH} / \mathrm{QR}$ mix 1 , and $14 \%$ for SH/QR mix 1 . The nanoformulations exhibited a strong inhibition effect in regards to PFU: $98.5 \pm 1.23 \%$ for $\mathrm{MSNs}-\mathrm{NH}_{2}-\mathrm{SH}, \quad 83.0 \pm 0.23 \%$ for MSNs- $\mathrm{NH}_{2}-\mathrm{QR}$, and $95.2 \pm 0.3 \%$ for $\mathrm{MSNs}-\mathrm{NH}_{2}-\mathrm{SH}-\mathrm{QR} 2$. MSNs-NH 2 -SH-QR1 had a weaker effect (27\%). MSNs$\mathrm{NH}_{2}-\mathrm{SH}, \mathrm{MSNs}-\mathrm{NH}_{2}-\mathrm{QR}$, and MSNs-NH${ }_{2}-\mathrm{SH}-\mathrm{QR} 2$ exhibited significantly stronger effects $(\mathrm{p}<0.05)$ than all others used. Regarding the effect of a double amount of particles for MSNs-NH ${ }_{2}-\mathrm{SH}-\mathrm{QR} 2$ compared to $\mathrm{MSNs}_{-} \mathrm{NH}_{2}-\mathrm{SH}-\mathrm{QR} 1$, we observed enhanced inhibition of the number of PFU, a similar trend as with titer inhibition. Therefore, an increased concentration of nanoparticles in formulation induces a stronger effect of inhibition.

All prodrugs had a weaker effect that did not reach 15\%. As far as nanoformulations are concerned, only $\mathrm{MSNs}-\mathrm{NH}_{2}-$ $\mathrm{SH}$ and $\mathrm{MSNs}-\mathrm{NH}_{2}-\mathrm{SH}-\mathrm{QR} 2$ significantly inhibited PFU at $48 \mathrm{hpi}$, to $100 \%$ and $93.9 \pm 1.2 \%$, respectively, and a weaker effect was seen with $\mathrm{MSNs}-\mathrm{NH}_{2}-\mathrm{QR}(14 \%)$ and $\mathrm{MSNs}-\mathrm{NH}_{2}$ -SH-QR1 (9\%). The nanoparticles and prodrugs also exhibited weaker and negligible inhibition effects compared to MSNs- $\mathrm{NH}_{2}-\mathrm{SH}$ and MSNs-NH${ }_{2}-\mathrm{SH}-\mathrm{QR} 2$.

The plaque reduction assay is an accurate method due to the direct quantification of infectious viruses from in vitro cell culture. ${ }^{81}$ Therefore, the results are particularly relevant for assessing real antiviral effects compared to HI assay, which counts all dead and live plaques. A strong antiviral effect against $\mathrm{H} 5 \mathrm{~N} 1$ was found for the nanoformulations MSNs- $\mathrm{NH}_{2}-\mathrm{SH}$ and MSNs-NH ${ }_{2}-\mathrm{SH}-\mathrm{QR} 2$.

It is known that the phenolic structure of $\mathrm{SH}$ results in several pharmacological effects, including antiviral, antioxidant, anticancer, and antibacterial. ${ }^{82}$ Additionally, regarding the role of prodrug, the antiviral effects of $\mathrm{SH}$ could be due to its phenolic chemical structure, as reported for anti-influenza natural prodrug substances with a phenolic structure from medicinal plants. ${ }^{83,84}$

However, the nanoformulations were more efficient than $\mathrm{SH}$ in the free form. Also, the unloaded nanoparticles showed no antiviral effect. In particular, a significant inhibition of $\mathrm{H} 5 \mathrm{~N} 1$ virus by MSNs- $\mathrm{NH}_{2}-\mathrm{SH}$ was observed even at a small loading of 3 wt.\%.
This may be attributed to the targeting effect, where the prodrug is directly transferred from the nanoformulation to the virus surface when they are in close contact. Mutual attraction of the virus and nanoformulation particle is plausible due to its interaction with capsid protein through carboxylic groups of SH molecules. Another factor contributing to attraction could be electrostatic effects, as nanoformulations had negative zeta potential (at basic $\mathrm{pH}$ condition) as shown in zeta potential results (Figure 3C).

The discussed below results address in more detail the main mechanism of MSNs- $\mathrm{NH}_{2}-\mathrm{SH}$ and $\mathrm{MSNs}-\mathrm{NH}_{2}-\mathrm{SH}-$ $\mathrm{QR} 2$ action against $\mathrm{H} 5 \mathrm{~N} 1$ virus.

\section{The IC50 of Effective Nanoformulations}

The results presented in Figure 5B show that $\mathrm{MSNs}_{-} \mathrm{NH}_{2}-\mathrm{SH}$ significantly inhibited PFU with all used concentrations, and the IC50 was $42.2 \mu \mathrm{g} / \mathrm{mL}$. Full inhibition (100\%) for PFU was obtained with $75 \mu \mathrm{g} / \mathrm{mL}$. The IC50 value for $\mathrm{MSNs}^{-\mathrm{NH}_{2}}$ -SH-QR2was $72.3 \mu \mathrm{g} / \mathrm{mL}$. However, this nanoformulation reached only $86.5 \pm 0.5 \%$ with a nanoparticle concentration of $150 \mu \mathrm{g} / \mathrm{mL}$ compared to $\mathrm{MSNs}-\mathrm{NH}_{2}-\mathrm{SH}$. These findings confirm that SH-based nanoformulation has superior antiviral activity against the inhibition of A/duck/Egypt/ Q5569D/2012 (H5N1) influenza virus compared to QR loaded in combination, even though a double amount of nanoparticles was used. Therefore, $\mathrm{SH}$ is highly recommended as a prodrug candidate for novel nanotherapeutic formulations against infectious diseases. For comparison with antiviral drug, testing the sensitivity of the H5N1 virus toward zanamivir showed that $\mathrm{H} 5 \mathrm{~N} 1$ virus was sensitive to zanamivir with IC50 $<1.66 \mu \mathrm{g} / \mathrm{mL}$ after 48 hpi.

\section{Mechanism of the Nanoformulation's Antiviral Action} The viral-infection stages (direct effect on virus or during replication after virus attaches to host cells or during adsorption to host cells) play an important role in targeting viruses. ${ }^{16,19,28,85}$ To investigate the underlying mechanism of the effective nanoformulations $\left(\mathrm{MSNs}-\mathrm{NH}_{2}-\mathrm{SH}\right.$ and MSNs- $\mathrm{NH}_{2}-\mathrm{SH}-\mathrm{QR} 2$ ) action against $\mathrm{H} 5 \mathrm{N1}$ virus, three main possible antiviral mechanisms representing the viralinfection stages were considered.

(i) blocking access of the virus to the cells by blocking of the host cell receptor to hinder the initial step of infection, inhibiting the viral entry (viral adsorption);

(ii) interference with intracellular viral replication (viral replication); and 
(iii) direct inactivation of the viral particle (virucidal activity).

The above modes of actions could account for antiviral activities either independently or in combination. ${ }^{85}$ The experiments based on plaque reduction assay are a standard method to evaluate the mechanisms of viral action. This assay is done in three different ways to be able to estimate how the nanoformulations could affect the three viral-infection stages. The results are described in Figure $6 \mathrm{~A}$ and a schematic representation of the virus inactivation mechanism is shown in Figure 6B.

Concerning the viral adsorption mechanism, when the virus was treated with $\mathrm{MSNs}-\mathrm{NH}_{2}-\mathrm{SH}-\mathrm{QR} 2$, a negligible reduction in plaque formation was detected. A small inhibition of plaques was found with $\mathrm{MSNs}-\mathrm{NH}_{2}-\mathrm{SH}$ treatment, indicating that the latter nanoformulation reduces viral adsorption to MDCK cells to a certain extent (Figure 6A, a and b).

Regarding the suppression of the intracellular viral replication, $\mathrm{H} 5 \mathrm{~N} 1$ virus treated with $\mathrm{MSNs}-\mathrm{NH}_{2}-\mathrm{SH}$ resulted in relatively small plaques compared to treatment with MSNs$\mathrm{NH}_{2}$-SH-QR2. The formation of a small number of plaques compared to untreated control, especially in the case of MSNs- $\mathrm{NH}_{2}-\mathrm{SH}$, indicating the possibility of inhibiting the virus via this mechanism to some extent (Figure 6A, c and d).
Concerning the viricidal mechanism (iii), no plaque formation confirms that the main action of both nanoformulations is virucidal activity (Figure 6A, e and f). The virucidal mechanism is probably due to direct and strong attraction between nanoformulations and the virus glycoproteins ${ }^{26}$ present on the surface of H5N1, thus sequestering it at early infection stages.

We assume that the nanoformulations antiviral effect against the $\mathrm{H} 5 \mathrm{~N} 1$ is caused by targeting the viruses, which leads to direct contact between the virus and nanoformulations particle, and as a consequence its inactivation. Thus, mechanism (iii) from the above mentioned is presumably active.

Direct interaction is facilitated by the fact that the nanoformulation particle and the virus are of similar size. Attraction and contact are presumably caused by the interaction between carboxylic groups (leading to negative charge of $\mathrm{SH}$ in nanoformulations) and amine groups of the glycoproteins (as HA) on the virus surface. The SH or QR molecules migrating from nanoformulation to the virus may effectively inhibit viral proteins and prevent penetration of the virus into the cells.

In this regard, the shikimic pathway is the key intermediate in the synthesis of oseltamivir phosphate, the FDAapproved drug known as Tamiflu ${ }^{\circledR}$, an efficient NA enzyme inhibitor used in the treatment of influenza infection. ${ }^{86}$
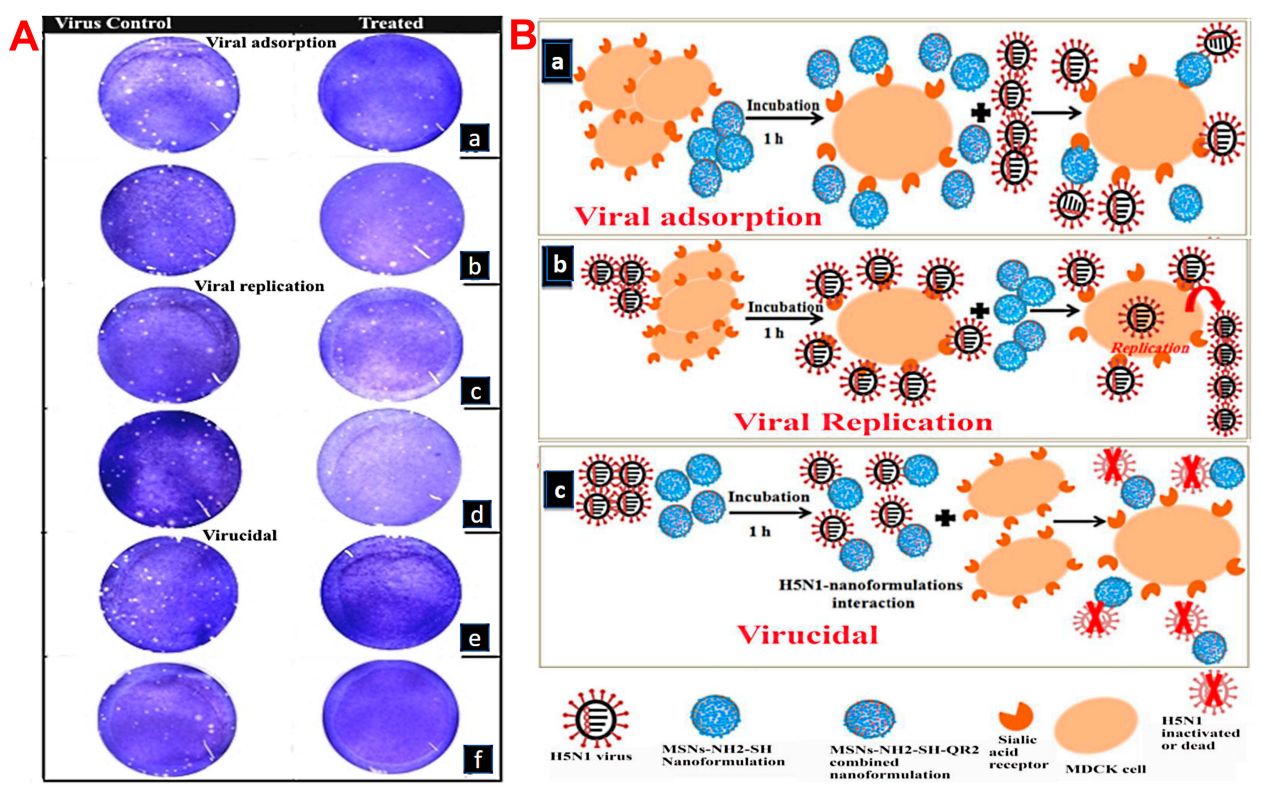

Figure 6 Antiviral mechanisms of nanoformulations tested by plaque reduction assay.

Notes: Plaque formation (white dots) appeared or disappeared in response to the tested mode of action of the nanoformulations (A). Left: virus control. Right: treated

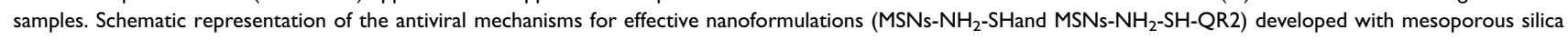
nanoparticles (B). a) Virucidal mechanism. b) Viral replication mechanism. c) Viral adsorption mechanism.

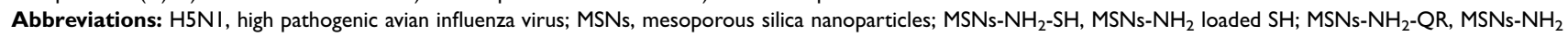
loaded QR; MSNs-NH $2-\mathrm{SH}-\mathrm{QR2}$, MSNs-NH 2 loaded $\mathrm{SH}$ and $\mathrm{QR}$ and was used in twice amount; MDCK, Madin-Darby Canine Kidney cells. 
Consequently, it prevents the virus from attaching to MDCK cells. ${ }^{16,20,28,87}$

In conclusion, the main mechanism virucidal activity is probably a direct interaction of the nanoformulations with the $\mathrm{H} 5 \mathrm{~N} 1$ virus, which leads to its inactivation at early infection stages. This main effect may be accompanied by additional effects on viral replication and adsorption, especially for MSNs- $\mathrm{NH}_{2}-\mathrm{SH}$. In future practical applications of such nanoformulations, they can be administered by means of oral or injection routes depending on the possible application of MSNs. This is in line with the practical application of antiviral drugs such as oseltamivir.

\section{Immunomodulatory Evaluations Effects of Tested Materials on Lymphocyte Cell Viability}

To perform immunological experiments, we initially assessed the effects of nanoparticles, prodrugs, and nanoformulations on lymphocyte cell viability (Figure 7A). At a concentration of $25 \mu \mathrm{g} / \mathrm{mL}$, we found no differences between cells treated with nanoparticles, prodrugs, and nanoformulations. The cell viability was more than $96 \%$. At a concentration of $50 \mu \mathrm{g} / \mathrm{mL}$, decreased viability was observed for some treatments.

The cell viability was less for MSNs (90\%) than MSNs- $\mathrm{NH}_{2}$ (98\%). High viability was found for cells treated with $\mathrm{SH}(93 \%), \mathrm{QR}(96 \%)$, and $\mathrm{SH} / \mathrm{QR}$ mix.1 (94\%), but a significantly lower viability was found for SH/QR mix.2 (70\%). In addition, high viability was found with MSNs- $\mathrm{NH}_{2}-\mathrm{SH}$ (100\%), MSNs- $\mathrm{NH}_{2}-\mathrm{QR}$ (100\%), and $\mathrm{MSNs}-\mathrm{NH}_{2}-\mathrm{SH}-\mathrm{QR} 1$ (100\%), but it decreased to $70 \%$ for $\mathrm{MSNs}-\mathrm{NH}_{2}-\mathrm{SH}-\mathrm{QR} 2$.

At a concentration of $100 \mu \mathrm{g} / \mathrm{mL}$, significant differences were found between prodrugs and nanoformulations compared to nanoparticles. MSNs (92\%) and MSNs- $\mathrm{NH}_{2}$ $(100 \%)$ resulted in high viability compared to prodrugs and nanoformulations. MSNs- $\mathrm{NH}_{2}-\mathrm{SH}, \mathrm{MSNs}-\mathrm{NH}_{2}-\mathrm{QR}$, and $\mathrm{MSNs}-\mathrm{NH}_{2}-\mathrm{SH}-\mathrm{QR} 1$ resulted in cell viability in the range of $70-80 \%$. However, cells treated with $\mathrm{MSNs}-\mathrm{NH}_{2}-$ SH-QR2 had $53 \%$ viability. For prodrugs, viability was in the range of $60-80 \%$. Again, SH/QR mix.2 demonstrated the strongest effect (58\%).

The greatest cytotoxic effect was found when cells were treated with $100 \mu \mathrm{g} / \mathrm{mL}$ compared to $25 \mu \mathrm{g} / \mathrm{mL}$ and $50 \mu \mathrm{g} / \mathrm{mL}$. Consequently, $25 \mu \mathrm{g} / \mathrm{mL}$ was selected as a safe dose for subsequent investigations. Our results for nanoparticles agree with results in human peripheral blood lymphocytes treated with silica nanoparticles in vitro. ${ }^{88,89}$

\section{Effects of Nanoformulations on Lymphocyte} Stimulation Index

The lymphocyte proliferative response to mitogen, expressed as the lymphocyte stimulation index (LSI),
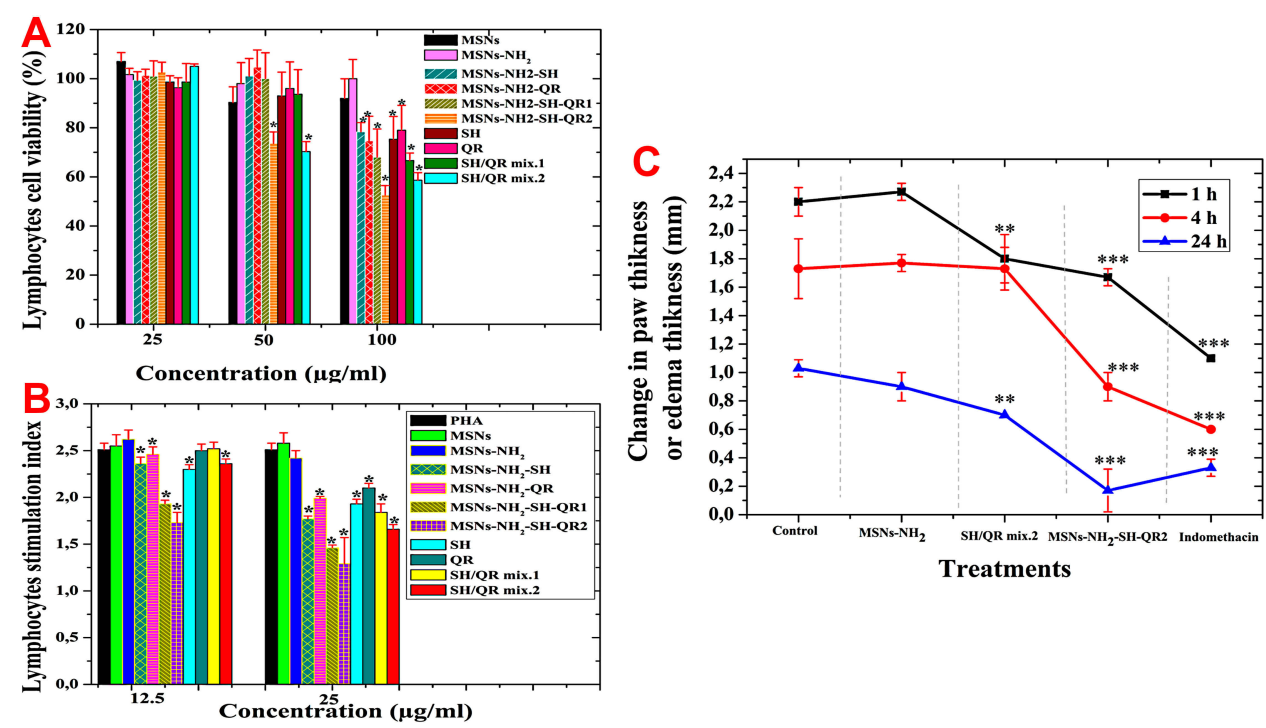

Figure 7 In vitro cytotoxicity evaluation immune cells and in vivo anti-inflammatory. Lymphocyte cell viability with nanoparticles, modified nanoparticles, prodrugs and their mixtures, nanoformulations, and combined nanoformulations (A). Lymphocyte index for nanoparticles, modified nanoparticles, prodrugs and their mixtures, nanoformulations, and combined nanoformulations (B). Anti-inflammatory activity in carrageenan-induced rats as the change in paw thickness (mm) (C). Data are expressed as mean \pm SD. ${ }^{*}<<0.05$, medium significance $(* *)$ and high significance $(* * *)$.

Abbreviations: MSNs, mesoporous silica nanoparticles; $M S N s-\mathrm{NH}_{2}$, MSNs modified amino groups; $M S N_{s}-\mathrm{NH}_{2}-\mathrm{SH}, \mathrm{MSNs}^{-} \mathrm{NH}_{2}$ loaded $\mathrm{SH}$; $M S N s-\mathrm{NH}_{2}-\mathrm{QR}$, $\mathrm{MSNs}-\mathrm{NH}_{2}$ loaded QR; MSNs- $\mathrm{NH}_{2}-\mathrm{SH}-\mathrm{QRI}$, MSNs- $\mathrm{NH}_{2}$ loaded $\mathrm{SH}$ and $\mathrm{QR} ; \mathrm{MSNs}-\mathrm{NH}_{2}-\mathrm{SH}-\mathrm{QR2}$ was used in twice amount; SH/QR mix.I, mixture of SH and QR; SH/QR mix.2, mixture of $\mathrm{SH}$ and $\mathrm{QR}$ used in twice amount; $\mathrm{SH}$ pure, shikimic acid; QR pure, quercetin; IC50, the half-maximal inhibitory concentration; SD, standard deviation. 
reflects the potential to enhance or inhibit cellular immunity in response to treatment. LSI $\leq 2.5$ indicates suppression of lymphocyte proliferation, whereas LSI $\geq 2.5$ indicates enhanced lymphocyte cell division. When lymphocytes are exposed to PHA as a stimulus (PHAstimulated cells), it triggers high production of cytokines and other immunomodulators. ${ }^{90}$ We can perform tests to explore the effects of samples on the LSI (Figure 7B). At $12.5 \mu \mathrm{g} / \mathrm{mL}$, the nanoparticles did not show any significant differences from untreated control, with an LSI close to 2.5. Prodrugs showed different responses: $\mathrm{SH}$ and $\mathrm{SH} / \mathrm{QR}$ mix. 2 significantly suppressed the LSI to $2.2 \pm 0.04$ and $2.3 \pm 0.04$, respectively. $\mathrm{QR}$ and $\mathrm{SH} / \mathrm{QR}$ mix. 1 had results similar to the control.

Nanoformulations significantly $(\mathrm{p}<0.05)$ suppressed the LSI (MSNs-NH $2-\mathrm{SH}, 2.3 \pm 0.07$; MSNs-NH$H_{2}-\mathrm{QR}$, $2.4 \pm 0.08$; MSNs-NH2-SH-QR1, $1.9 \pm 0.03$; and MSNs$\left.\mathrm{NH}_{2}-\mathrm{SH}-\mathrm{QR} 2,1.7 \pm 0.10\right)$. Interestingly, as the concentration increased to $50 \mu \mathrm{g} / \mathrm{mL}$, significantly high suppression was observed when nanoformulations and prodrugs were used. The strongest suppression effect was found for nanoformulations, followed by prodrugs. The lowest inhibition of LSI was seen when cells were treated with $\mathrm{MSNs}-\mathrm{NH}_{2}-$ SH-QR2 (1.29 \pm 0.28$)$. These findings demonstrate that the LSI is concentration dependent. Our results are in line with the previous studies in which lymphocytes activated by PHA were used (eg, resveratrol ${ }^{91}$ and Yerba mate Ilex paraguariensis $).^{92}$ As nanoformulations containing a concentration equivalent to $25 \mu \mathrm{g} / \mathrm{mL}$ of prodrug inhibited immune $\mathrm{T}$ lymphocyte proliferation, they have a beneficial effect as anti-inflammatory or immunomodulation factors, leading to the activation of different molecular signaling pathways in the development of diseases, such as autoimmune diseases, bacterial and viral infection, and cancers. This effect may be due to the drug carrier nanostructure of MSNs mediating the inhibition of lymphocytes $^{93}$ and associated with the prodrug activities, such as antioxidant activity. ${ }^{94}$

\section{Effect of Nanoformulations on LPS-Induced Nitric Oxide, TNF- $\alpha$, and IL-I $\beta$ Levels in vitro}

The innate immune system includes phagocyte compartments (macrophages, neutrophils, and dendritic cells), proteins, and natural killer cells. ${ }^{95}$ The neutrophils produce the first defensive action against an attack in innate immunity, but the macrophages are most important for the activation of inflammatory responses. ${ }^{96}$ High amounts of various kinds of cytokines (eg, TNF- $\alpha$, IL-1 $\beta$, IL-6) and NO are secreted by macrophages. Thus, they play a crucial role in regulating immunopathological phenomena throughout the inflammation reactions for various diseases.

Several studies have demonstrated that a high concentration of TNF- $\alpha$ is detected after influenza A virus infection, suggesting a pivotal role in the pathogenesis of $\mathrm{H} 5 \mathrm{~N} 1$ disease. $^{97,98}$ As presented in Table 3, the treatment of LPSstimulated murine peritoneal macrophages with $25 \mu \mathrm{g} / \mathrm{mL}$ of nanoformulation markedly inhibited the production of TNF- $\alpha$ compared to nanoparticles and prodrugs. Both MSNs $(2388 \pm$ $7 \mathrm{pg} / \mathrm{mL})$ and $\mathrm{MSNs}-\mathrm{NH}_{2}(2235 \pm 39)$ had non-significant

Table 3 Inhibitory Effects of Combined Nanoformulations on Nitric Oxide (NO), TNF- $\alpha$, and IL-I $\beta$ After Stimulation with LPS in vitro

\begin{tabular}{|c|c|c|c|}
\hline Inflammatory Stimulation and Treatment & NO $(\mu \mathrm{M} / \mathrm{mL})$ & TNF- $\alpha(\mathrm{pg} / \mathrm{mL})$ & IL-I $\beta(p g / m L)$ \\
\hline Control & $2.69 \pm 0.03^{i}$ & $10.3 \pm 0.33^{h}$ & $10.3 \pm 0.33^{h}$ \\
\hline LPS (inducer) & $30.21 \pm 0.33^{\mathrm{a}}$ & $2315.84 \pm 47.68^{\mathrm{abc}}$ & $674.68 \pm 5.43^{\mathrm{a}}$ \\
\hline MSNs & $30.7 \pm 0.43^{\mathrm{a}}$ & $2387.66 \pm 62.9^{\mathrm{ab}}$ & $671.27 \pm 2.22^{\mathrm{a}}$ \\
\hline MSNs-NH ${ }_{2}$ & $29.65 \pm 0.27^{\mathrm{a}}$ & $2234.77 \pm 38.74^{c}$ & $663.44 \pm 10.9^{\mathrm{a}}$ \\
\hline $\mathrm{MSNs}-\mathrm{NH}_{2}-\mathrm{SH}$ & $22.3 \pm 0.07^{\mathrm{e}}$ & $2025.17 \pm 10.59^{d}$ & $590.95 \pm 2.12^{d}$ \\
\hline MSNs-NH ${ }_{2}-\mathrm{QR}$ & $24.15 \pm 0.06^{c}$ & $2295.57 \pm 8.77^{\mathrm{bc}}$ & $645.03 \pm 1.75^{b}$ \\
\hline MSNs-NH $2-\mathrm{SH}-\mathrm{QRI}$ & $16.78 \pm 0.04^{g}$ & $1571.66 \pm 22.18^{f}$ & $500.24 \pm 4.44^{f}$ \\
\hline MSNs-NH $2-S H-Q R 2$ & $14.76 \pm 0.13^{\mathrm{h}}$ & $1180.55 \pm 13.45^{8}$ & $422.02 \pm 2.69^{g}$ \\
\hline SH Pure & $23.66 \pm 0.19^{\mathrm{cd}}$ & $2223.92 \pm 28.13^{c}$ & $630.7 \pm 5.63^{b}$ \\
\hline QR Pure & $25.1 \pm 0.17^{b}$ & $2434.24 \pm 24.68^{\mathrm{a}}$ & $672.76 \pm 4.94^{\mathrm{a}}$ \\
\hline SH/QR mix.I & $22.92 \pm 0.28^{\mathrm{de}}$ & $2115.3 \pm 40.34^{d}$ & $608.97 \pm 8.07^{c}$ \\
\hline SH/QR mix.2 & $21.3 \pm 0.14^{f}$ & $1879.57 \pm 20.06^{e}$ & $561.83 \pm 4.0 \mathrm{I}^{\mathrm{e}}$ \\
\hline
\end{tabular}

Notes: Different letters in the same column indicate significant differences in the reduction of cytokine and NO levels according to post hoc Fisher Duncan test ( $p<0.05$ ). Data are expressed as mean \pm SD.

Abbreviations: NO, nitric oxide; TNF- $\alpha$, tumor necrosis factor-alpha; IL-I $\beta$, cytokines interleukin; LPS, lipopolysaccharide; MSNs, mesoporous silica nanoparticles; MSNs$\mathrm{NH}_{2}$, MSNs modified amino groups; $\mathrm{MSNs}-\mathrm{NH}_{2}-\mathrm{SH}, \mathrm{MSNs}-\mathrm{NH}_{2}$ loaded $\mathrm{SH} ; \mathrm{MSNs}-\mathrm{NH}_{2}-\mathrm{QR}, \mathrm{MSNs}-\mathrm{NH}_{2}$ loaded QR; $M S N s-\mathrm{NH}_{2}-\mathrm{SH}-\mathrm{QRI}, \mathrm{MSNs}-\mathrm{NH} \mathrm{H}_{2}$ loaded SH and QR; MSNs- $\mathrm{NH}_{2}-\mathrm{SH}-\mathrm{QR} 2$ was used in twice amount; $\mathrm{SH} / \mathrm{QR}$ mix. I, mixture of $\mathrm{SH}$ and QR; SH/QR mix.2, mixture of $\mathrm{SH}$ and QR used in twice amount; $\mathrm{SH}$ pure, shikimic acid; QR pure, quercetin. 
effects compared to LPS-stimulated macrophages (2316 \pm $48 \mathrm{pg} / \mathrm{mL}$ ). However, the effects were significant for $\mathrm{SH} / \mathrm{QR}$ mix.2 (1880 $\pm 20 \mathrm{pg} / \mathrm{mL})$ and $\mathrm{SH} / \mathrm{QR} \operatorname{mix} .1$ (2115 \pm $40 \mathrm{pg} / \mathrm{mL}$ ), but $\mathrm{SH}$ and $\mathrm{QR}$ showed no significant effects. Interestingly, MSNs-NH $2-\mathrm{SH}-\mathrm{QR} 1$ and MSNs-NH $\mathrm{N}_{2}-\mathrm{SH}-\mathrm{QR} 2$ had significantly $(\mathrm{p}<0.05)$ stronger efficacy for inhibiting TNF- $\alpha$ secretion $(\mathrm{pg} / \mathrm{mL})$ in cells $(1180 \pm 13$ and $1572 \pm 22$, respectively) compared to LPS-induced treatment. MSNs$\mathrm{NH}_{2}-\mathrm{SH}$ exhibited a moderate inhibition effect $(2025 \pm 10$ $\mathrm{pg} / \mathrm{mL}$ ), whereas $\mathrm{MSNs}-\mathrm{NH}_{2}-\mathrm{QR}$ had no significant effect. Overall, the nanoformulations, especially $\mathrm{MSNs}_{-} \mathrm{NH}_{2}-\mathrm{SH}-$ QR2 and MSNs- $\mathrm{NH}_{2}-\mathrm{SH}-\mathrm{QR} 1$, were the most significantly effective form for inhibiting TNF- $\alpha$, providing strong evidence of their immunomodulatory impact.

As shown in Table 3, treatment with nanoparticles had a small effect on IL-1 $\beta$ concentrations compared to LPSinduced macrophages. For prodrugs, SH/QRmix2 had a greater effect than $\mathrm{SH} / \mathrm{QR}$ mix1 and $\mathrm{SH}$ to reduce IL-1 $\beta$ concentrations compared to control LPS-induced macrophages. Alternatively, QR had no important effect on IL-1 $\beta$. Nanoformulations significantly inhibited IL-1 $\beta$ secretion (MSNs-NH $2-\mathrm{SH}-\mathrm{QR} 2,422 \pm 3 \mathrm{pg} / \mathrm{mL} ; \mathrm{MSNs}_{2}-\mathrm{NH}_{2}-\mathrm{SH}-$ $\mathrm{QR} 1,500 \pm 4 \mathrm{pg} / \mathrm{mL}$; LPS-induced macrophages, $2316 \pm 5$ $\mathrm{pg} / \mathrm{mL}$ ). MSNs-NH $\mathrm{H}_{2}-\mathrm{SH}-\mathrm{QR} 2$ and $\mathrm{MSNs}_{-} \mathrm{NH}_{2}-\mathrm{SH}-\mathrm{QR} 1$ are potent IL-1 $\beta$ inhibitors, followed by $\mathrm{MSNs}-\mathrm{NH}_{2}-\mathrm{SH}(591 \pm 2$ $\mathrm{pg} / \mathrm{mL})$ and $\mathrm{MSNs}-\mathrm{NH}_{2}-\mathrm{QR}(645.0 \pm 1.7 \mathrm{pg} / \mathrm{mL})$ as moderate inhibitors.

NO is an important messenger in the modulation of immune responses, as it is responsible for regulating macrophage cytotoxicity and contributes to its antiviral role. ${ }^{99,100}$ LPS can significantly enhance the levels of nitrite, which is considered a stable oxidized form of NO in medium. ${ }^{101}$ Treatment of LPS-stimulated cells with nanoparticles, prodrugs, and nanoformulations resulted in different effects (Table 3). MSNs and MSNs- $\mathrm{NH}_{2}$ did not significantly inhibit NO. In contrast, prodrugs significantly reduced NO concentrations in LPS-stimulated cells as follows: $\mathrm{SH} / \mathrm{QR}$ mix $2>$, SH/QR mix $1>$, $\mathrm{SH}>\mathrm{QR}$. As expected, the nanoformulations also significantly inhibited $\mathrm{NO}$; MSNs-NH${ }_{2}-\mathrm{SH}-\mathrm{QR} 2(14.76 \pm 0.13 \mu \mathrm{M} / \mathrm{mL})$ and MSNs- $\mathrm{NH}_{2}-\mathrm{SH}-\mathrm{QR} 1(16.78 \pm 0.04 \mu \mathrm{M} / \mathrm{mL})$ were particularly strong inhibitors of NO compared to LPS-stimulated macrophages $(30.2 \pm 0.3 \mu \mathrm{M} / \mathrm{mL})$, followed by MSNs$\mathrm{NH}_{2}$-SH $(22.3 \pm 0.07 \mu \mathrm{M} / \mathrm{mL})$ and $\mathrm{MSNs}-\mathrm{NH}_{2}-\mathrm{QR}(24.15$ $\pm 0.06 \mu \mathrm{M} / \mathrm{mL}$ ) with moderate action.

These findings confirm that the treatment of macrophages with nanoparticles does not modulate cytokine (TNF- $\alpha$ and IL-1 $\beta$ ) and NO production compared to LPS- stimulated macrophages. They have a similar effect as LPS-stimulated cells. Prodrugs had a moderate inhibitory effect, especially with $\mathrm{SH} / \mathrm{QR}$ mix.2. $\mathrm{SH}$ seems to be a stronger inhibitor than QR. However, they still are not adequate to modulate the three examined parameters. The nanoformulations, especially $\mathrm{MSNs}-\mathrm{NH}_{2}-\mathrm{SH}-\mathrm{QR} 2$ and MSNs- $\mathrm{NH}_{2}-\mathrm{SH}-\mathrm{QR} 1$, exert a strong inhibitory effect on the secretion of TNF- $\alpha$, IL- $1 \beta$, and NO in LPS-stimulated macrophages. Consequently, this desirable effect depends on SH and QR being carried by nanoparticles.

It seems that the mechanism by which the nanoformulations modulate inflammatory mediators within immune cells is complex. As the nanoformulation consists of prodrugs and nanoparticles, one can expect that there are two possible mechanisms, one related to the prodrug effect and one related to the nanoparticle effect. Regarding the prodrug effect, for SH-treated LPS-induced macrophages in vitro and in vivo, suppression of NO, TNF- $\alpha$, and IL-1 $\beta$ occurs through the ERK $1 / 2$ and p38 phosphorylation pathway. ${ }^{102}$ Their down-regulation by $\mathrm{SH}$ can be through inhibition of nuclear factor-kappa B $(\mathrm{NF}-\kappa \mathrm{B})$ via the phosphorylation of signaling proteins in the mitogen-activated protein kinase (MAPK) family. ${ }^{103}$ As regulatory signaling, the MAPK cascade (including ERK, c-Jun N-terminal kinases (JNKs), and p38 phosphorylation) is accountable for various functions in macrophages. ${ }^{104}$ Inhibition of the MAPK pathway by different inhibitors results in block release and prevents the action of inflammatory cytokines, including TNF- $\alpha$ and IL- $1 \beta,{ }^{105}$ as well as the synthesis of NO. Several studies have indicated the capacity of QR to modulate pro-inflammatory cytokines and NO in LPS-stimulated macrophages through the MAPK and NF- $\mathrm{KB}$ pathways and other pathways. ${ }^{106,107}$

Concerning the nanoparticle effect, depending on their unique physicochemical characteristics, nanoparticles interact with immune cells and proteins, causing stimulation or suppression of the innate immune responses. ${ }^{108}$ In this context, some studies have indicated that nanoformulations largely enhance suppression of pro-inflammatory cytokines and NO, comparable to drugs evaluated in LPSstimulated macrophages. ${ }^{105,109}$ We think the superior results for our nanoformulations provide evidence that their immunomodulation/anti-inflammatory actions occur through the MAPK signaling pathway; consequently, they would play critical roles in targeted inflammatory diseases.

At the same time, we propose an indirect link between the immunomodulatory effect and the results of the inhibition of H5N1 virus. Several previous studies have shown 
the relationship between the immunomodulation effect and virus inhibition. ${ }^{42-46}$

\section{Anti-Inflammatory Effect of Combined Nanoformulations in vivo}

We confirmed the anti-inflammatory effects described above using an animal model of inflammation induced by carrageenan in the paws of rats. This is a well-known model used in the development of anti-inflammatory drugs. We selected the effective nanoformulation (MSNs$\mathrm{NH}_{2}$-SH-QR2) and compared it to MSNs, mixed pure prodrugs, and standard drugs used in therapy (indomethacin). As shown in Figure $7 \mathrm{C}$, treatment with mixed SH-QR2, MSNs-NH ${ }_{2}$-SH-QR2, and indomethacin significantly $(\mathrm{p}<0.05)$ reduced the paw thickness at $1 \mathrm{~h}$ to $1.8 \pm$ $0.17 \mathrm{~mm}, 1.6 \pm 0.07 \mathrm{~mm}$, and $1.10 \pm 0.1 \mathrm{~mm}$, respectively, compared to $2.2 \pm 0.1 \mathrm{~mm}$ and $2.27 \pm 0.06 \mathrm{~mm}$ for controls and MSNs. In addition, SH/QR mix.2 and MSNs$\mathrm{NH}_{2}$-SH-QR2 had similar efficacy in reducing paw edema at $1 \mathrm{~h}$, but MSNs-NH $\mathrm{N}_{2}-\mathrm{SH}-\mathrm{QR} 2 \mathrm{had}$ an enhanced effect at $4 \mathrm{~h}$ and $24 \mathrm{~h}$ compared to SH-QR2. Furthermore, indomethacin had a superior capacity to suppress inflammation-induced paw swelling compared to MSNs- $\mathrm{NH}_{2}-\mathrm{SH}$ -QR2 at early time points ( $1 \mathrm{~h}$ and $4 \mathrm{~h}$ ), but had almost similar anti-inflammatory properties to $\mathrm{MSNs}^{-\mathrm{NH}_{2}-\mathrm{SH}-}$ QR2 at $24 \mathrm{~h}$ (Figure 7C). The observed delayed reduction in paw edema by MSNs-SH-QR2 could possibly be due to the slow release of $\mathrm{SH}$ and $\mathrm{QR}$ from MSNs. Another possibility is the enhancement of the solubility and bioavailability of prodrugs in nanoformulations compared to pure mixed compounds.

These findings indicate that MSNs- $\mathrm{NH}_{2}-\mathrm{SH}-\mathrm{QR} 2$ is more effective over a long period of time than the pure mixed prodrugs of SH-QR2 and indomethacin. The enhanced efficacy of MSNs- $\mathrm{NH}_{2}-\mathrm{SH}-\mathrm{QR} 2$ in vivo is in agreement with results obtained from in vitro studies, which suggests that inhibition of inflammation-induced paw edema could be attributed to down-regulation of pro-inflammatory cytokine and NO levels. MSNs- $\mathrm{NH}_{2}-\mathrm{SH}-\mathrm{QR} 2$ modulates immune responses and may find its application as an antiinflammatory agent to replace synthetic drugs, such as indomethacin, in the near future. Our results are consistent with previous studies investigating nanoscale preparations and pure forms of drugs/bioactive compounds in carrageenaninduced inflammation in Wistar rats when treated with $\alpha$ tocopheryl polyethylene glycol 1000 succinate-stabilized curcumin nanoparticles, ${ }^{110}$ and dexamethasone drug loaded in a lipid nanostructure carrier. ${ }^{111}$

\section{Conclusions}

For the first time, we propose an effective antiviraltargeted nanoformulation where natural prodrugs inactivate avian influenza virus $\mathrm{H} 5 \mathrm{~N} 1$. The nanoformulation consist of mesoporous silica nanospheres (MSN) functionalized with amine groups $\left(\mathrm{NH}_{2}\right)$ and loaded with shikimic acid $(\mathrm{SH})$ or quercetin $(\mathrm{QR})$ prodrugs. The nanoformulations displayed both an antiviral and anti-inflammatory effect.

MSNs- $\mathrm{NH}_{2}-\mathrm{SH}$ and $\mathrm{MSNs}-\mathrm{NH}_{2}-\mathrm{SH}-\mathrm{QR} 2$ cause full inhibition of both virus titers and plaque formation 48 hpi. The nanoparticles and prodrugs alone are less efficient as antiviral formulations than the drug-loaded mesospheres. The effect depends on the concentration of nanoparticles in the nanoformulation. SH was particularly efficient in fighting the virus, even for low loading into MSNs, compared to QR. MSNs- $\mathrm{NH}_{2}-\mathrm{SH}$ and MSNs- $\mathrm{NH}_{2}-$ SH-QR2 displayed a stronger antiviral effect. The main mechanism of antiviral action of the nanoformulations against H5N1 was through direct interaction between the virus and nanoparticles, which inactivates the virus at early stages.

MSNs- $\mathrm{NH}_{2}-\mathrm{SH}-\mathrm{QR} 2$ followed by $\mathrm{MSNs}-\mathrm{NH}_{2}-\mathrm{SH}$ has the strongest inhibitory effect on inflammatory modulators NO, TNF- $\alpha$, and IL- $1 \beta$, reducing them to more than $50 \%$ of their concentration in immune macrophages. The efficient modulatory effect results in superior anti-inflammatory activity in an in vivo animal model. Loading of two prodrugs into MSNs opens the way towards multidrug-hold nanoformulations for novel nanotherapeutic applications.

The proposed nanoformulations against avian H5N1 virus could effectively act as novel antiviral agents through direct (virucidal mechanism) and indirect (immunomodulatory effects) pathways. First preliminary results have been obtained towards the development of a novel therapy of influenza infections, as well as antiinflammatory nanotherapy.

\section{Funding}

This work was supported by the National Research Centre (NRC, Egypt)and under NRC-internal research project fund 11010310. We thank the Egyptian Science and Technology Development Fund (STDF, Egypt) for funding under grant 5175. Many thanks to the National Center for Research and Development, Poland (STRATEGMED3/ 306888/3/NCBR/2017, project iTE, Poland). Part of the research was carried out using equipment funded by the 
project CePT Poland, reference: POIG.02.02.00-14-024/ 08, European Regional Development Fund for Poland, Operational Programme "Innovative Economy" for 2007-2013. Special acknowledgement: The authors dedicate this work to spirit of our co-author Dr. Asmaa M.M. Salman from the National Research Centre (NRC, Egypt). She passed away as a result of her long struggle with disease during the preparation of the manuscript to resubmit to the journal.

\section{Disclosure}

The authors report no conflicts of interest in this work.

\section{References}

1. Galdiero S, Falanga A, Vitiello M, Cantisani M, Marra V, Galdiero M. Silver nanoparticles as potential antiviral agents. Molecules. 2011;16 (10):8894-8918. doi:10.3390/molecules16108894

2. Kuiken T, Riteau B, Fouchier RA, Rimmelzwaan GF. Pathogenesis of influenza virus infections: the good, the bad and the ugly. Curr Opin Virol. 2012;2(3):276-286. doi:10.1016/j.coviro.2012.02.013

3. Richard M, de Graaf M, Herfst S. Avian influenza A viruses: from zoonosis to pandemic. Future Virol. 2014;9(5):513-524. doi:10. 2217/fvl.14.30

4. Alam MI, Mostafa A, Kanrai P, et al. Verapamil has antiviral activities that target different steps of the influenza virus replication cycle. J Antivir Antiretrovir. 2016;8(4):121-130.

5. Yang J, Li M, Shen X, Liu S. Influenza A virus entry inhibitors targeting the hemagglutinin. Viruses. 2013;5(1):352-373. doi:10. 3390/v5010352

6. Houser KV, Katz JM, Tumpey TM. Seasonal trivalent inactivated influenza vaccine does not protect against newly emerging variants of influenza A (H3N2v) virus in ferrets. $J$ Virol. 2013;87 (2):1261-1263. doi:10.1128/JVI.02625-12

7. Greber Urs F. How cells tune viral mechanics-insights from biophysical measurements of influenza virus. Biophys J. 2014;106 (11):2317-2321. doi:10.1016/j.bpj.2014.04.025

8. Gefenaite G, Rahamat-Langendoen J, Ambrozaitis A, et al. Seasonal influenza vaccine effectiveness against influenza in 2012-2013: a hospital-based case-control study in Lithuania. Vaccine. 2014;32(7):857-863. doi:10.1016/j.vaccine.2013.12.021

9. Valenciano M, Kissling E, Cohen J-M, et al. Estimates of pandemic influenza vaccine effectiveness in europe, 2009-2010: results of influenza monitoring vaccine effectiveness in Europe (I-MOVE) multicentre case-control study. PLoS Med. 2011;8(1):e1000388. doi:10.1371/journal.pmed.1000388

10. Hayden FG, de Jong MD. Emerging Influenza Antiviral Resistance Threats. J Infect Dis. 2011;203(1):6-10. doi:10.1093/infdis/jiq012

11. Cagno V, Andreozzi P, D'Alicarnasso M, et al. Broad-spectrum non-toxic antiviral nanoparticles with a virucidal inhibition mechanism. Nat Mater. 2017;17(2):195. doi:10.1038/nmat5053

12. Mirza AZ, Siddiqui FA. Nanomedicine and drug delivery: a mini review. Int Nano Lett. 2014;4(1):94. doi:10.1007/s40089-014-0094-7

13. Sokolova V, Westendorf AM, Buer J, Uberla K, Epple M. The potential of nanoparticles for the immunization against viral infections. J Mater Chem B. 2015;3(24):4767-4779. doi:10.10 39/C5TB00618J

14. Szunerits S, Barras A, Khanal M, Pagneux Q, Boukherroub R. Nanostructures for the Inhibition of Viral Infections. Molecules. 2015;20(8):14051. doi:10.3390/molecules200814051
15. Xiang D-X, Chen Q, Pang L, Zheng C-L. Inhibitory effects of silver nanoparticles on H1N1 influenza A virus in vitro. $J$ Virol Methods. 2011;178(1-2):137-142. doi:10.1016/j.jviromet.2011.09.003

16. Yang XX, Li CM, Huang CZ. Curcumin modified silver nanoparticles for highly efficient inhibition of respiratory syncytial virus infection. Nanoscale. 2016;8(5):3040-3048. doi:10.1039/C5NR07918G

17. Fujimori $Y$, Sato $T$, Hayata $T$, et al. Novel antiviral characteristics of nanosized copper(I) iodide particles showing inactivation activity against 2009 pandemic H1N1 influenza virus. Appl Environ Microbiol. 2012;78(4):951-955. doi:10.1128/AEM.06284-11

18. Ye S, Shao K, Li Z, et al. Antiviral activity of graphene oxide: how sharp edged structure and charge matter. ACS Appl Mater Interfaces. 2015;7(38):21571-21579. doi:10.1021/acsami.5b06876

19. DeRussy BM, Aylward MA, Fan Z, Ray PC, Tandon R. Inhibition of cytomegalovirus infection and photothermolysis of infected cells using bioconjugated gold nanoparticles. Sci Rep. 2014;4(1):5550. doi:10.1038/srep05550

20. Papp I, Sieben C, Ludwig K, et al. Inhibition of influenza virus infection by multivalent sialic-acid-functionalized gold nanoparticles. Small. 2010;6(24):2900-2906. doi:10.1002/smll.201001349

21. Tao W, Hurst BL, Shakya AK, et al. Consensus M2e peptide conjugated to gold nanoparticles confers protection against $\mathrm{H} 1 \mathrm{~N} 1$, H3N2 and H5N1 influenza A viruses. Antiviral Res. 2017;141:62-72. doi:10.1016/j.antiviral.2017.01.021

22. Kwon S-J, Na DH, Kwak JH, et al. Nanostructured glycan architecture is important in the inhibition of influenza A virus infection. Nat Nano. 2017;12(1):48-54. doi:10.1038/nnano.2016.181

23. Ho RJ, Yu J, Li B, et al. Systems Approach to targeted and long-acting HIV/AIDS therapy. Drug Deliv Transl Res. 2015;5 (6):531-539. doi:10.1007/s13346-015-0254-y

24. Shao J, Kraft JC, Li B, et al. Nanodrug formulations to enhance HIV drug exposure in lymphoid tissues and cells: clinical significance and potential impact on treatment and eradication of HIV/ AIDS. Nanomedicine. 2016;11(5):545-564. doi:10.2217/nnm.16.1

25. Sillman B, Bade AN, Dash PK, et al. Creation of a long-acting nanoformulated dolutegravir. Nat Commun. 2018;9(1):443. doi:10.1038/s41467-018-02885-x

26. Osminkina LA, Timoshenko VY, Shilovsky IP, et al. Porous silicon nanoparticles as scavengers of hazardous viruses. J Nanopart Res. 2014;16(6):2430. doi:10.1007/s11051-014-2430-2

27. de Souza ESJM, Hanchuk TD, Santos MI, Kobarg J, Bajgelman MC, Cardoso MB. Viral inhibition mechanism mediated by surface-modified silica nanoparticles. ACS Appl Mater Interfaces. 2016;8(26):16564-16572. doi:10.1021/acsami.6b03342

28. Lee EC, Davis-Poynter N, Nguyen CTH, et al. GAG mimetic functionalised solid and mesoporous silica nanoparticles as viral entry inhibitors of herpes simplex type 1 and type 2 viruses. Nanoscale. 2016;8(36):16192-16196. doi:10.1039/C6NR03878F

29. Tarn D, Ashley CE, Xue M, Carnes EC, Zink JI, Brinker CJ. Mesoporous Silica nanoparticle nanocarriers: biofunctionality and biocompatibility. Acc Chem Res. 2013;46(3):792-801. doi:10.1021/ ar3000986

30. Liberman A, Mendez N, Trogler WC, Kummel AC. Synthesis and surface functionalization of silica nanoparticles for nanomedicine. Surf Sci Rep. 2014;69(2-3):132-158. doi:10.1016/j.surfrep.2014.07.001

31. Heidegger S, Schmidt A, Schmidt A, et al. Immune response to functionalized mesoporous silica nanoparticles for targeted drug delivery. Nanoscale. 2016;8(2):938-948.

32. Shahein SA, Aboul-Enein AM, Higazy IM, et al. Targeted anticancer potential against glioma cells of thymoquinone delivered by mesoporous silica core-shell nanoformulations with $\mathrm{pH}$-dependent release. Int J Nanomedicine. 2019;14:5503-5526. doi:10.2147/IJN.S206899

33. AbouAitah K, Hassan HA, Swiderska-Sroda A, et al. Targeted nano-drug delivery of colchicine against colon cancer cells by means of mesoporous silica nanoparticles. Cancers. 2020;12 (1):144. doi:10.3390/cancers 12010144 
34. Fu C, Liu T, Li L, Liu H, Chen D, Tang F. The absorption, distribution, excretion and toxicity of mesoporous silica nanoparticles in mice following different exposure routes. Biomaterials. 2013;34(10):2565-2575. doi:10.1016/j.biomaterials.2012.12.043

35. Watermann A, Brieger J. Mesoporous silica nanoparticles as drug delivery vehicles in cancer. Nanomaterials. 2017;7(7):189.

36. Lin Y-S, Haynes CL. Impacts of mesoporous silica nanoparticle size, pore ordering, and pore integrity on hemolytic activity. $J \mathrm{Am}$ Chem Soc. 2010;132(13):4834-4842. doi:10.1021/ja910846q

37. Hussain SM, Hess KL, Gearhart JM, Geiss KT, Schlager JJ. In vitro toxicity of nanoparticles in BRL 3A rat liver cells. Toxicol Vitro. 2005;19(7):975-983. doi:10.1016/j.tiv.2005.06.034

38. Bradley D. Star role for bacteria in controlling flu pandemic? Nat Rev Drug Discov. 2005;4(12):945-946. doi:10.1038/nrd1917

39. Widmer N, Meylan P, Ivanyuk A, Aouri M, Decosterd LA, Buclin T. Oseltamivir in Seasonal, Avian H5N1 and Pandemic 2009 A/H1N1 Influenza. Clin Pharmacokinet. 2010;49(11):741-765. doi:10.2165/ 11534730-000000000-00000

40. Choi HJ, Song JH, Park KS, Kwon DH. Inhibitory effects of quercetin 3-rhamnoside on influenza A virus replication. Eur J Pharm Sci. 2009;37(3-4):329-333. doi:10.1016/j.ejps.2009.03.002

41. Wu W, Li R, Li X, et al. Quercetin as an antiviral agent inhibits influenza a virus (IAV) Entry. Viruses. 2016;8(1):6. doi:10.3390/ v8010006

42. Wang G, Zhang J, Li W, et al. Apoptosis and proinflammatory cytokine responses of primary mouse microglia and astrocytes induced by human $\mathrm{H} 1 \mathrm{~N} 1$ and avian $\mathrm{H} 5 \mathrm{~N} 1$ influenza viruses. Cell Mol Immunol. 2008;5(2):113-120. doi:10.1038/cmi.2008.14

43. Szretter KJ, Gangappa S, Lu X, et al. Role of host cytokine responses in the pathogenesis of avian $\mathrm{H} 5 \mathrm{~N} 1$ influenza viruses in mice. $J$ Virol. 2007;81(6):2736-2744. doi:10.1128/JVI. 02336-06

44. Sakabe S, Iwatsuki-Horimoto K, Takano R, et al. Cytokine production by primary human macrophages infected with highly pathogenic H5N1 or pandemic H1N1 2009 influenza viruses. J Gen Virol. 2011;92(Pt 6):1428-1434. doi:10.1099/vir.0.030346-0

45. Boon AC, Williams RW, Sinasac DS, Webby RJ. A novel genetic locus linked to pro-inflammatory cytokines after virulent $\mathrm{H} 5 \mathrm{~N} 1$ virus infection in mice. BMC Genomics. 2014;15(1):1017. doi:10.1186/1471-2164-15-1017

46. Van Reeth K, Van Gucht S, Pensaert M. Correlations between lung proinflammatory cytokine levels, virus replication, and disease after swine influenza virus challenge of vaccination-immune pigs. Viral Immunol. 2002;15(4):583-594. doi:10.1089/08828240232091 4520

47. Barbosa RPA, Salgado APC, Garcia CC, et al. Protective immunity and safety of a genetically modified influenza virus vaccine. PLoS One. 2014;9(6):e98685. doi:10.1371/journal.pone.0098685

48. Shen D, Yang J, Li X, et al. Biphase stratification approach to three-dimensional dendritic biodegradable mesoporous silica nanospheres. Nano Lett. 2014;14(2):923-932. doi:10.1021/n1404316v

49. AbouAitah KEA, Farghali AA, Swiderska-Sroda A, Lojkowski W, Razin AM, Khedr MK. pH-controlled release system for curcumin based on functionalized dendritic mesoporous silica nanoparticles. J Nanomed Nanotechnol. 2016;1(351):1-11.

50. Mosmann T. Rapid colorimetric assay for cellular growth and survival: application to proliferation and cytotoxicity assays. $J$ Immunol Methods. 1983;65(1-2):55-63. doi:10.1016/00221759(83)90303-4

51. Hayden FG, Cote KM, Douglas RG. Plaque inhibition assay for drug susceptibility testing of influenza viruses. Antimicrob Agents Chemother. 1980;17(5):865-870. doi:10.1128/AAC.17.5.865

52. Abdella AM, Moatasim Y, Ali MA, Elwahy AHM, Abdelhamid IA. Synthesis and anti-influenza virus activity of novel bis (4H-chromene-3-carbonitrile) Derivatives. J Heterocycl Chem. 2017;54(3):1854-1862. doi:10.1002/jhet.2776
53. Kuo Y-C, Lin L-C, Tsai W-J, Chou C-J, Kung S-H, Ho Y-H. Samarangenin B from limonium sinense suppresses herpes simplex virus type 1 replication in vero cells by regulation of viral macromolecular synthesis. Antimicrob Agents Chemother. 2002;46(9):2854-2864. doi:10.1128/AAC.46.9.2854-2864.2002

54. Zhang J, Zhan B, Yao X, Gao Y, Shong J. [Antiviral activity of tannin from the pericarp of Punica granatum L. against genital Herpes virus in vitro]. Zhongguo Zhong Yao Za Zhi. 1995;20 (9):556-558. Chinese.

55. Schuhmacher A, Reichling J, Schnitzler P. Virucidal effect of peppermint oil on the enveloped viruses herpes simplex virus type 1 and type 2 in vitro. Phytomedicine. 2003;10(6-7):504-510. doi:10.1078/094471103322331467

56. Riahi-Zanjani B, Balali-Mood M, Mohammadi E, Badie-Bostan H, Memar B, Karimi G. Safranal as a safe compound to mice immune system. Avicenna j Phytomed. 2015;5(5):441-449.

57. McPhillips KA, Erwig LP. Assessment of apoptotic cell phagocytosis by macrophages. Methods Mol Biol. 2009;559:247-256.

58. Gammelsrud A, Solhaug A, Dendele B, et al. Enniatin B-induced cell death and inflammatory responses in RAW 267.4 murine macrophages. Toxicol Appl Pharmacol. 2012;261(1):74-87. doi:10.1016/j.taap.2012.03.014

59. Choi YH, Kim GY, Lee HH. Anti-inflammatory effects of cordycepin in lipopolysaccharide-stimulated RAW 264.7 macrophages through Toll-like receptor 4-mediated suppression of mitogen-activated protein kinases and NF-kappaB signaling pathways. Drug Des Devel Ther. 2014;8:1941-1953. doi:10.2147/ DDDT.S71957

60. Ahn KS, Aggarwal BB. Transcription factor NF-kappaB: a sensor for smoke and stress signals. Ann N Y Acad Sci. 2005;1056 (1):218-233. doi:10.1196/annals.1352.026

61. Green LC, Wagner DA, Glogowski J, Skipper PL, Wishnok JS, Tannenbaum SR. Analysis of nitrate, nitrite, and $[15 \mathrm{~N}]$ nitrate in biological fluids. Anal Biochem. 1982;126(1):131-138. doi:10.10 16/0003-2697(82)90118-X

62. Morris CJ. Carrageenan-induced paw edema in the rat and mouse. Methods Mol Biol. 2003;225:115-121.

63. Arfan M, Amin H, Khan N, et al. Analgesic and anti-inflammatory activities of 11-O-galloylbergenin. J Ethnopharmacol. 2010;131 (2):502-504. doi:10.1016/j.jep.2010.06.040

64. Li Z, Su K, Cheng B, Deng Y. Organically modified MCM-type material preparation and its usage in controlled amoxicillin delivery. J Colloid Interface Sci. 2010;342(2):607-613. 10.10 16/j.jcis.2009.10.073

65. AbouAitah KEA, Farghali AA, Swiderska-Sroda A, Lojkowski W, Razin AM, Khedr MK. Mesoporous silica materials in drug delivery system: ph/glutathione-responsive release of poorly water-soluble pro-drug quercetin from two and three-dimensional pore-structure nanoparticles. J Nanomed Nanotechnol. 2016;1(360):1-12. doi:10.4172/ 2157-7439.1000360

66. Popova M, Szegedi A, Yoncheva K, et al. New method for preparation of delivery systems of poorly soluble drugs on the basis of functionalized mesoporous MCM-41 nanoparticles. Microporous Mesoporous Mater. 2014;198:247-255. doi:10.1016/j.micromeso.2014.07.044

67. AbouAitah K, Swiderska-Sroda A, Farghali AA, et al. Folic acid-conjugated mesoporous silica particles as nanocarriers of natural prodrugs for cancer targeting and antioxidant action. Oncotarget. 2018;9(41):26466-26490. doi:10.18632/oncotarget.25470

68. Horcajada P, Rámila A, Férey G, Vallet-Regí M. Influence of superficial organic modification of MCM-41 matrices on drug delivery rate. Solid State Sci. 2006;8(10):1243-1249. doi:10.1016/ j.solidstatesciences.2006.04.016

69. Jambhrunkar S, Qu Z, Popat A, et al. Effect of Surface Functionality of Silica Nanoparticles on Cellular Uptake and Cytotoxicity. Mol Pharm. 2014;11(10):3642-3655. doi:10.1021/ mp500385n 
70. Datt A, El-Maazawi I, Larsen SC. Aspirin loading and release from MCM-41 Functionalized with aminopropyl groups via co-condensation or postsynthesis modification methods. J Phys Chem C. 2012;116(34):18358-18366. doi:10.1021/jp3063959

71. Guo Z, Liu X-M, Ma L, et al. Effects of particle morphology, pore size and surface coating of mesoporous silica on Naproxen dissolution rate enhancement. Colloids Surf $B$ Biointerfaces. 2013;101:228-235. doi:10.1016/j.colsurfb.2012.06.026

72. Song SW, Hidajat K, Kawi S. Functionalized SBA-15 materials as carriers for controlled drug delivery: influence of surface properties on matrix-drug interactions. Langmuir. 2005;21(21):9568-9575. doi:10.1021/1a051167e

73. Lee C-H, Lo L-W, Mou C-Y, Yang C-S. Synthesis and characterization of positive-charge functionalized mesoporous silica nanoparticles for oral drug delivery of an anti-inflammatory drug. Adv Funct Mater. 2008;18(20):3283-3292. doi:10.1002/adfm.200800521

74. Wani A, Muthuswamy E, Savithra GHL, Mao G, Brock S, Oupický D. Surface functionalization of mesoporous silica nanoparticles controls loading and release behavior of mitoxantrone. Pharm Res. 2012;29(9):2407-2418. doi:10.1007/s11095-012-0766-9

75. Yoncheva K, Popova M, Szegedi A, et al. Functionalized mesoporous silica nanoparticles for oral delivery of budesonide. $J$ Solid State Chem. 2014;211:154-161. doi:10.1016/j.jssc.2013.12.020

76. Baghirov H, Karaman D, Viitala T, et al. Feasibility study of the permeability and uptake of mesoporous silica nanoparticles across the blood-brain barrier. PLoS One. 2016;11(8):e0160705. doi:10.1371/journal.pone.0160705

77. Ge Q, Pastey M, Kobasa D, et al. Inhibition of multiple subtypes of influenza a virus in cell cultures with morpholino oligomers. Antimicrob Agents Chemother. 2006;50(11):3724-3733. doi:10.11 28/AAC.00644-06

78. Chen D-Y, Shien J-H, Tiley L, et al. Curcumin inhibits influenza virus infection and haemagglutination activity. Food Chem. 2010;119(4):1346-1351. doi:10.1016/j.foodchem.2009.09.011

79. El-Sherif O, Khoo S, Solas C. Key drug-drug interactions with direct-acting antiviral in HIV-HCV coinfection. Curr Opin HIV AIDS. 2015;10(5):348-354. doi:10.1097/COH.0000000000000185

80. Schmidtke M, Schnittler U, Jahn B, Dahse HM, Stelzner A. A rapid assay for evaluation of antiviral activity against coxsackie virus B3, influenza virus A, and herpes simplex virus type 1. J Virol Methods. 2001;95(1-2):133-143. doi:10.1016/S0166-0934(01)00305-6

81. Baer A, Kehn-Hall K. Viral concentration determination through plaque assays: using traditional and novel overlay systems. $J$ Visualized Exp. 2014;93:e52065.

82. Estevez AM, Estevez RJ. A short overview on the medicinal chemistry of (-)-shikimic acid. Mini Rev Med Chem. 2012;12 (14):1443-1454. doi:10.2174/138955712803832735

83. Palamara AT, Nencioni L, Aquilano K, et al. Inhibition of influenza A virus replication by resveratrol. J Infect Dis. 2005;191 (10):1719-1729. doi:10.1086/429694

84. Pleschka S, Stein M, Schoop R, Hudson JB. Anti-viral properties and mode of action of standardized Echinacea purpurea extract against highly pathogenic avian influenza virus (H5N1, H7N7) and swine-origin H1N1 (S-OIV). Virol J. 2009;6(1):197. doi:10.1186/1743-422X-6-197

85. Baram-Pinto D, Shukla S, Gedanken A, Sarid R. Inhibition of HSV-1 attachment, entry, and cell-to-cell spread by functionalized multivalent gold nanoparticles. Small. 2010;6(9):1044-1050. doi:10.1002/smll.200902384

86. Ghosh S, Chisti Y, Banerjee UC. Production of shikimic acid. Biotechnol Adv. 2012;30(6):1425-1431. doi:10.1016/j.biotechadv. 2012.03.001

87. Li Y, Lin Z, Zhao M, et al. Silver nanoparticle based codelivery of oseltamivir to inhibit the activity of the H1N1 Influenza Virus through ROS-mediated signaling pathways. ACS Appl Mater Interfaces. 2016;8(37):24385-24393. doi:10.1021/acsami.6b06613
88. Lankoff A, Arabski M, Wegierek-Ciuk A, et al. Effect of surface modification of silica nanoparticles on toxicity and cellular uptake by human peripheral blood lymphocytes in vitro. Nanotoxicology. 2013;7(3):235-250. doi:10.3109/17435390.2011.649796

89. Heidegger S, Gossl D, Schmidt A, et al. Immune response to functionalized mesoporous silica nanoparticles for targeted drug delivery. Nanoscale. 2016;8(2):938-948. doi:10.1039/C5NR06122A

90. Ai W, Li H, Song N, Li L, Chen H. Optimal Method to Stimulate Cytokine Production and Its Use in Immunotoxicity Assessment. Int J Environ Res Public Health. 2013;10(9):3834-3842. doi:10.33 90/ijerph10093834

91. Boscolo P, Del Signore A, Sabbioni E, et al. Effects of resveratrol on lymphocyte proliferation and cytokine release. Ann Clin Lab Sci. 2003;33(2):226-231.

92. Munoz-Culla M, Saenz-Cuesta M, Guereca-Barandiaran MJ, Ribeiro ML, Otaegui D. Yerba mate (Ilex paraguariensis) inhibits lymphocyte activation in vitro. Food Funct. 2016;7(11):4556-4563. doi:10.1039/C6FO01061J

93. Przybylski S, Gasch M, Marschner A, et al. Influence of nanoparticle-mediated transfection on proliferation of primary immune cells in vitro and in vivo. PLoS One. 2017;12(5):e0176517. doi:10.1371/journal.pone.0176517

94. De la Fuente M, Victor VM. Anti-oxidants as modulators of immune function. Immunol Cell Biol. 2000;78(1):49-54. doi:10.10 46/j.1440-1711.2000.00884.x

95. Medzhitov R, Janeway C Jr. Innate immunity. $N$ Engl J Med. 2000;343(5):338-344. doi:10.1056/NEJM200008033430506

96. Aderem A, Ulevitch RJ. Toll-like receptors in the induction of the innate immune response. Nature. 2000;406(6797):782-787. doi:10. $1038 / 35021228$

97. Chan RWY, Leung CYH, Nicholls JM, Peiris JSM, Chan MCW. Proinflammatory cytokine response and viral replication in mouse bone marrow derived macrophages infected with influenza H1N1 and H5N1 viruses. PLoS One. 2012;7(11):e51057. doi:10.1371/ journal.pone.0051057

98. Nain M, Hinder F, Gong JH, et al. Tumor necrosis factor-alpha production of influenza A virus-infected macrophages and potentiating effect of lipopolysaccharides. J Immunol. 1990;145 (6):1921-1928.

99. Mayer B, Hemmens B. Biosynthesis and action of nitric oxide in mammalian cells. Trends Biochem Sci. 1997;22(12):477-481. doi:10.1016/S0968-0004(97)01147-X

100. Nathan C. Nitric oxide as a secretory product of mammalian cells. FASEB j. 1992;6(12):3051-3064. doi:10.1096/fasebj.6.12.1381691

101. Gao Y, Jiang W, Dong C, et al. Anti-inflammatory effects of sophocarpine in LPS-induced RAW 264.7 cells via NF-kappaB and MAPKs signaling pathways. Toxicol Vitro. 2012;26(1):1-6. doi:10.1016/j.tiv.2011.09.019

102. Rabelo TK, Guimaraes AG, Oliveira MA, et al. Shikimic acid inhibits LPS-induced cellular pro-inflammatory cytokines and attenuates mechanical hyperalgesia in mice. Int Immunopharmacol. 2016;39:97-105. doi:10.1016/j.intimp.2016.07.016

103. Manna K, Khan A, Das D, et al. Protective effect of coconut water concentrate and its active component shikimic acid against hydroperoxide mediated oxidative stress through suppression of NF- $\mathrm{B}$ and activation of Nrf2 pathway. J Ethnopharmacol. 2014;155 (1):132-146. doi:10.1016/j.jep.2014.04.046

104. Lloberas J, Valverde-Estrella L, Tur J, Vico T, Celada A. Mitogenactivated protein kinases and mitogen kinase phosphatase 1: a critical interplay in macrophage biology. Fron Mol Biosci. 2016;3:28. doi:10.3389/fmolb.2016.00028

105. Kumar RP, Abraham A. Inhibition of LPS induced pro-inflammatory responses in RAW 264.7 macrophage cells by PVP-coated naringenin nanoparticle via down regulation of NF-kappaB/P38MAPK mediated stress signaling. Pharmacol Rep. 2017;69(5):908-915. doi:10.1016/j.pharep.2017.04.002 
106. Qureshi AA, Tan X, Reis JC, et al. Suppression of nitric oxide induction and pro-inflammatory cytokines by novel proteasome inhibitors in various experimental models. Lipids Health Dis. 2011;10(1):177. doi:10.1186/1476-511X-10-177

107. Nair MP, Mahajan S, Reynolds JL, et al. The flavonoid quercetin inhibits proinflammatory cytokine (tumor necrosis factor alpha) gene expression in normal peripheral blood mononuclear cells via modulation of the NF- $\kappa \beta$ System. Clin Vaccine Immunol. 2006;13(3):319-328. doi:10.1128/CVI.13.3.319-328. 2006

108. Liu Y, Hardie J, Zhang X, Rotello VM. Effects of engineered nanoparticles on the innate immune system. Semin Immunol. 2017;34:25-32. doi:10.1016/j.smim.2017.09.011
109. Bains BK, Greene MK, McGirr LM, Dorman J, Farrow SN, Scott CJ. Encapsulation of the p38 MAPK inhibitor GSK 678361A in nanoparticles for inflammatory-based disease states. J Interdiscip Nanomed. 2016;1(3):85-92. doi:10.1002/jin2.9

110. Rachmawati H, Safitri D, Pradana AT, Adnyana IK. TPGSstabilized curcumin nanoparticles exhibit superior effect on carrageenan-induced inflammation in wistar rat. Pharmaceutics. 2016;8(3):24. doi:10.3390/pharmaceutics8030024

111. Xu X, Zhao $\mathrm{C}$, Yang $\mathrm{H}$, Jian $\mathrm{Y}$, Zhang Z, Huang Y. Antiinflammatory activity of injectable dexamethasone acetate-loaded nanostructured lipid carriers. Drug Deliv. 2011;18(7):485-492. doi:10.3109/10717544.2011.589087

\section{Publish your work in this journal}

The International Journal of Nanomedicine is an international, peerreviewed journal focusing on the application of nanotechnology in diagnostics, therapeutics, and drug delivery systems throughout the biomedical field. This journal is indexed on PubMed Central, MedLine, CAS, SciSearch ${ }^{\mathbb{R}}$, Current Contents ${ }^{\mathbb{R}} /$ Clinical Medicine, $^{2}$
Journal Citation Reports/Science Edition, EMBase, Scopus and the Elsevier Bibliographic databases. The manuscript management system is completely online and includes a very quick and fair peer-review system, which is all easy to use. Visit http://www.dovepress.com/ testimonials.php to read real quotes from published authors. 